4 nordon 



\section{Innovative Green Public Procurement of Construction, IT and Transport Services in Nordic countries}

PlanMiljø, december 2009 
Innovative Green Public Procurement of Construction, IT and Transport Services in Nordic countries

TemaNord 2010:529

(C) Nordic Council of Ministers, Copenhagen 2010

ISBN 978-92-893-2031-3

Cover photo: Image Select

This publication is available as Print on Demand (PoD) and can be ordered on

www.norden.org/order. Other Nordic publications are available at www.norden.org/en/publications.

Nordic Council of Ministers

Ved Stranden 18

DK-1061 København K

Phone (+45) 33960200

Fax (+45) 33960202

\section{Nordic Council}

Ved Stranden 18

DK-1061 København K

Phone (+45) 33960400

Fax (+45) 33111870

www.norden.org

\section{Nordic co-operation}

Nordic co-operation is one of the world's most extensive forms of regional collaboration, involving Denmark, Finland, Iceland, Norway, Sweden, and three autonomous areas: the Faroe Islands, Greenland, and Åland.

Nordic co-operation has firm traditions in politics, the economy, and culture. It plays an important role in European and international collaboration, and aims at creating a strong Nordic community in c strong Europe.

Nordic co-operation seeks to safeguard Nordic and regional interests and principles in the global community. Common Nordic values help the region solidify its position as one of the world's most innovative and competitive. 


\section{Content}

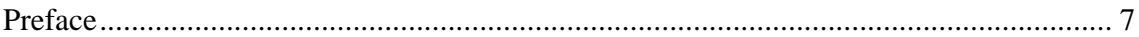

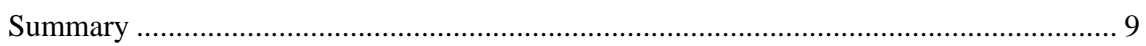

Recommendations for a Nordic Action Plan for IGPP ............................................ 10

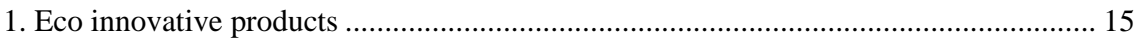

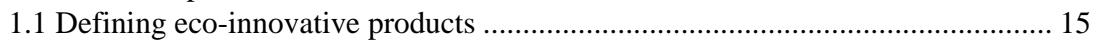

1.2 Environmental consequences of product development - a case ............................ 17

2 International experience with Innovative Green Public Procurement.............................. 19

2.1 Innovative Green Public Procurement............................................................... 19

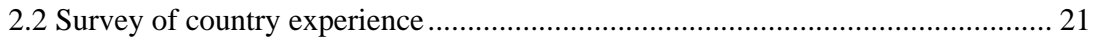

2.3 Specific IGPP initiatives of interest...................................................................... 25

3 Assessment of product and service groups in public procurement ............................... 29

3.1 Main product groups in Nordic public procurement........................................... 29

3.2 Environmentally important products in PP....................................................... 32

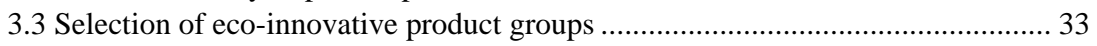

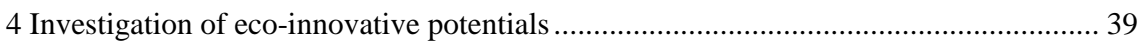

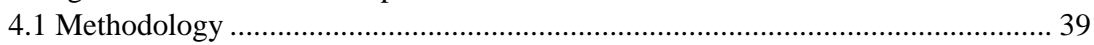

4.2 Construction work ...................................................................................... 41

4.3 IT products and related service........................................................................ 45

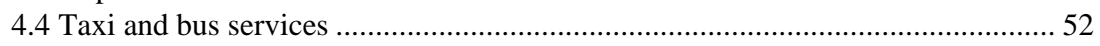

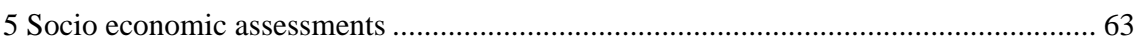

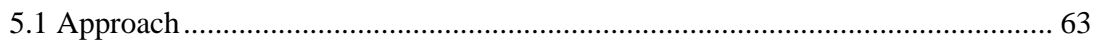

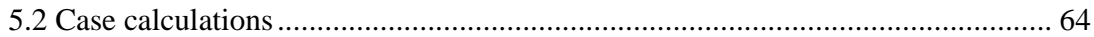

6 Strategical viewpoints on Innovative Green Public Procurement in Nordic Countries.. 75

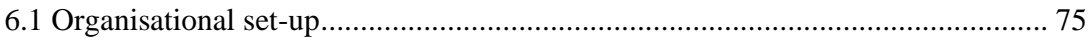

6.2 Proposed key contents in possible action plans on IGPP in Nordic countries ....... 85

6.3 Ideas concerning action plans for construction work........................................... 89

6.4 Ideas concerning action plans for IT products and services ............................... 91

6.5 Ideas concerning action plans for taxi and bus services ..................................... 92

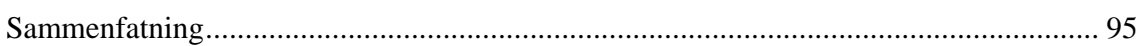

Anbefalinger til Nordisk handlingsplan for IGGP .................................................. 96

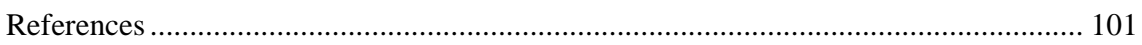





\section{Preface}

The interest in green innovative demands in public procurement is growing internationally and experience with green innovative procurement exists in several Nordic countries, the EU and the USA.

The Nordic Environmental Action Plan 2005-2008 points at the necessity of developing and using innovative environmental technologies that can decople environmental impact from economic growth. The Integrated Product Policy Group of the Nordic Council of Ministers (NMRIPP) aims at supporting green innovation through public and private procurement in line with the Nordic Environmental Action Plan.

The Nordic Innovation Policy Cooperation Programme (Det Nordiska Innovationspolitiska Samarbetsprogrammet) 2005-2010 has the long term objective to develop new sustainable products through future synergies between research in environmental technologies, innovation, strong competition skills and the use of cross-border public procurement. Innovative green public procurement - IGPP - is one of the tools that may play an important role in this endeavour towards more sustainable production.

The goal of the project is that the perspectives of IGPP have been made clear and that policy makers are aware of the potential benefits of IGPP and of strategy elements on how to promote eco-innovation through public procurement.

The project has had the overall objective to provide a clear and well structured review of how public procurement can enhance the volume of sales of environmentally innovative products and services in the Nordic countries. The project has been accomplished by PlanMiljø Denmark (project lead), Jegrelius Sweden, makeITgreen Norway, FCG-Efeko Finland. Thus, COWI has assisted with the socio economic assessment.

The team has consisted of:

Tomas Sander Poulsen (Project manager), Bjørn Bauer, Tue Dybkjær, from PlanMiljø ApS, Denmark

Lena Stigh from Jegrelius, Sweden

Erich Wessel from makeITgreen, Norway

Satu Hyrkkanen from Efeko, Finland

Eva Willumsen, Mads Paabøl Jensen from COWI, Denmark 
The project was initiated by the Integrated Product Policy group of the Nordic Council of Ministers (NMRIPP-group) and steered by it's subgroup for Greener Public Purchasing (GPP-group). Nordic Council of Ministers expresses it's gratitude for the project team for collecting interesting examples and viewpoints and making the synthesis and proposal for further work regarding this important policy instrument in the field of sustainable consumption and production.

Stockholm, 26 November 2009, on behalf of the steering group, Bente Ncess, chair 


\section{Summary}

The term Innovative Green Public Procurement (IGGP) is used widely in this project, and comprise all public procurement activities, which seek to stimulate eco-innovation through demands and interaction with suppliers and other stakeholders with the purpose of improving the environmental performance of products and services. Innovative Green Public Procurement can be examples of technology procurement as well as precommercial procurement or others.

The following criteria have determined Innovative Green Public Procurement:

1. The products have been through an innovative process leading to a new organizational or technological standard

2. The products have been procured by public institutions

3. The innovative process has provided environmental improvements

4. The supplier(s) is (are) from the private sector

On basis of an assessment of the volume in Nordic public procurement and the environmental issues for major public procurement product groups, three product groups can be identified as especially relevant for an analysis of the potential benefits and challenges of IGPP:

- Construction work

- Computers and related services

- Taxi and bus services

The eco-innovative potentials for the three selected product groups are investigated in a Nordic context through a desk study and a series of interviews with key stakeholders in the Nordic countries. The purpose was to form a picture of the potential environmental benefits that can be achieved in the Nordic countries through IGPP.

The survey includes:

- Identification of the eco-innovative potential of each product group

- Estimates of environmental effects

- Relevant incentives for stimulating eco-innovation through public procurement

- Barriers for exploiting the eco-innovation potential

- Input to strategies for innovative green public procurement 


\section{Recommendations for a Nordic Action Plan for IGPP}

Successful seeking of eco-innovative solutions necessitates clear processes for the identification of needs and timely and effective engagement with the market ${ }^{1}$. Below are highlighted a number of important activities necessary for enabling more eco-innovation in relation to the selected product groups (construction, IT and transport services) through proactive public procurement.

The action plans should naturally be founded and further developed on the basis of the existing bilateral national and sectoral plans and policies in the Nordic countries.

\section{Organisation of tenders in two steps}

A central precondition for enabling eco-innovative processes is extended communication with the complete value chain combined with thorough assessment of needs and technical/organizational opportunities.

New models for tendering are needed especially for procurement of construction work and IT. "Two step tendering" has provided valuable results in terms of integrating new technological and organisational solutions with environmental requirements:

1. Interaction and dialogue between the organisation inviting tenders and the potential tenderers concerning needs, options/solutions and possible ways forward.

2. The actual tendering process.

This procedure for organisation of tenders is also prescribed in the "competitive dialogue procedure" introduced in the public sector procurement directive (2004/18/EC) and implemented in the Public Contracts Regulation (SI 2006/5) which came into force 31. January 2006. It is for use in the award of complex ocntracts, where there is a need for the contracting authorities to discuss all aspects of the proposed contract with candidates.

National level institutions should identify appropriate models for more dialogue in tender processes. Especially regarding tenders for construction work (a complex sector with solutions adapted to local conditions), dialogue is needed if the desired services and products should go beyond standardised solutions.

Within the transport sector it is relevant to provide incentives that stimulate use of vehicles with alternative fuels or with fuel-saving technology. Thus, initiatives to provide and secure the necessary infrastructure for alternative fuels should be activated at the same time.

\footnotetext{
${ }^{1}$ Finding and Procuring Innovative Solutions; Department for Innovation, Universities and Skills, the UK Office of Government Commerce, 2007. a
} 


\section{Performance based tender criteria}

In public tenders it is common to use criteria based on specific technical standards concerning e.g. limit values for $\mathrm{SO} 2$ emissions or particles. However, using technically based criteria requires considerable technical knowledge in the public procurement institutions and need for regular updating of this knowledge. To enable more eco-innovative solutions, performance based criteria are a useful alternative instrument to ensure an open scope for solutions. Performance based criteria are easy to use in tender processes and they provide an "innovative room" for the supplier. An example of performance based criteria could be "lowest possible $\mathrm{CO}_{2}$ emission pr. km transport”. Thus, this is not a requirement as such but an award criteria. This means the tender can offer high $\mathrm{CO}_{2}$ emission and still be awarded the contract. To be sure to award a contract with low $\mathrm{CO}_{2}$ emission, the performance criteria should be supplemented with a stated maximum emission level.

Especially in relation to procurement of IT services, performance criteria should be applied more widely, e.g. for energy use and data capacity. By using performance criteria for IT services, chances for getting the newest technologies are higher. In the survey, several examples of tender processes ending up with old technologies were identified. The typical situation is, that the procurement process takes approx. three years from issuing the tender to receiving the equipment and meanwhile the technological development have overtaken the specifications in the tender and "state of art" IT equipment is far ahead in performance, than the delivered (which fully complete the specifications written three years ago). By using performance criteria it is possible to ensure "state of art" equipment at delivery date. This can be further enhanced by using contract constructions which include incentives for continuous improvements, or value engineering. To ensure that equipment or services is in accordance with the technical development, contract clauses should be applied

National initiatives for ensuring incorporation of performance criteria for energy use etc. in tenders for procurement of IT services should be established.

\section{Framework agreement with risk sharing}

For IT services and construction, it is relevant to consider a wider use of framework agreements with selected eco innovative suppliers where the procurement institution is willing to test and buy products without the traditional standard documentation and guarantees. Some division of risk between procurement institution and suppliers is necessary if new products and services are to be developed. The construction sector is highly influenced by standards and requirements on documentation and this culture is a barrier for enhanced development of eco-innovative solutions. The need for more examples of eco-innovative construction work may be met through increased use of framework contracts. 
A responsible national coordination body should initiate policy development and dialogue with relevant procurement institutions and supplier representatives concerning point of views and models on risk sharing in connection with public procurement of construction work.

Extended use of dedicated EU programmes for public procurement of innovation supporting measures.

EU has initiated specific programmes to promote innovation and ecoinnovation. The Nordic participation in these programmes has been relatively sparse and utilization of these funding opportunities might be improved. The CIP programme is in particular dedicated to eco-innovation initiatives within IT services, Life+ is dedicated to policy level, capacity building and awareness raising, Seventh framework programme is especially focusing on transport and energy saving, and Lead Market covers a.o. construction work.

Both at national level and Nordic level, initiatives for specific ecoinnovative projects should be developed to ensure external funding for further progress with eco-innovative public procurement. Thus, Motiva and Culminatum Innovation from Finland are participating in a EUfunded LMI-project concerning sustainable construction network for public procurers and Kolding municipality from Denmark participates in the EU funded "Smart SPP" project.

Development of eco-innovative procurement policy programmes

At national level the competent body should develop an IGPP policy programme for selected product groups

Improved integration of Life Cycle Cost in public procurement

In general, there is a need for more knowledge and information about the particular life cycle cost when evaluating proposals. Especially for construction work and for IT services, the life cycle cost is an important part of the decision making. Legal initiatives should be considered to ensure more documentation on LCC from suppliers during the tender process as a part of decision making.

Further, coordination between the procurement body and the operational body, e.g. in relation to housing, should in general be improved and the main criteria for selection of products/services should be based on cheapest in a life cycle perspective (up front + operating cost) and not, as common today, the up front cost only.

Financial support where stimulation is necessary

The socio economic survey of the scenarios within the selected product groups provides a number of interesting points. Strict economic logic dictates that the market for eco-innovative IT server systems will increase automatically due to the technologies” obvious economic benefits. But so 
far experience shows that this is still far from the case. National efforts should therefore be made in terms of information campaigns and more demonstration projects, serving as inspiration for public procurers of IT systems. Also catalytic procurement and activities may serve as drivers for users, within or beyond the public sector.

For low energy buildings the situation is different. Economic estimates indicate that low energy buildings are not economically feasible even in a long term perspective with the stated cost for standard and low energy buildings. With present energy prices and under the given assumptions, the procuring organisation must accept a certain price rise compared to traditional construction techniques.

Regulatory actions are taken from the EU, e.g., in the form of a Directive on energy labelling of buildings and requirements for low energy standards in all new building constructions etc. However, it may very well be considered of particular interest for the Nordic countries to be first movers within this sector, since the Nordic countries have many material suppliers, consultants and contractors as well as an attractive platform for export of product and services. National efforts should therefore focus on activating instruments, such as tax reductions, direct financial support, regulation etc. to boost development of eco-innovative buildings.

In relation to taxi services national attention should be on providing the necessary infrastructure and incentives for introduction and use of alternative vehicles, e.g. based on electricity.

Spreading and multiplying best practises

When the Nordic experiences with IGGP will exceed in the coming years, it is important to ensure appropriate coordination and dissemination of best practise. Not only at national level but also at the Nordic level. Initiatives to coordinate this dissemination among the Nordic countries, should be established. 



\section{Eco innovative products}

A common definition of eco-innovation is a prerequisite for enabling formulation of strategies for eco-innovative procurement. The below discussion of the term is followed by an empirical demonstration of the potential benefits of green procurement.

Nordic Council of Ministers has during the last years, supported this theme in different projects ${ }^{2}$.

\subsection{Defining eco-innovative products}

The term Eco-Innovation is derived from the two mutually independent concepts of Eco-friendly and Innovation.

Eco-Friendly

"Eco" is short for "eco-friendly". Eco-friendly products have a lower environmental impact than comparable products on the market seen in a life cycle perspective. An eco-friendly product is not environmentally optimal but constitutes the market lead in environmental terms. The relative environmental benefits are measured against the present situation or the situation before the product was developed.

The life cycle perspective aims at including environmental characteristics from all phases of the product life - from extraction of raw materials through the production stage, over utilization of the product to the waste phase. Environmental benefits are as a minimum considered in qualitative terms of avoided emissions or waste amounts. More precise calculations may include quantitative measures for avoided emissions, and even more thorough and significant life cycle assessments include qualitative and quantitative measures for the environmental impact.

This project works with a narrow sustainability concept not including cultural and socio economic factors.

\section{Innovation}

The notion of "innovation" covers products or processes that are developed intentionally and targeting a market with the aim of fulfilling a need and aiming at benefiting somebody (i.e. a group of people, an organisa-

\footnotetext{
${ }^{2}$ How central authorities can support ecodesign. Company perspectives www.norden.org/da/ publikationer/publikationer/2008-569/
} 
tion or the society) ${ }^{3}$. Innovation that is being developed or adopted may be new to the world or new to the context.

Innovation is closely related - but not similar - to creativity: "Creativity" is a mind based process of developing new ideas, whereas "innovation" in a more physical way concretizes the ideas into actual actions or products ${ }^{4}$.

Innovation is:

“... the process of bringing any new problem-solving idea into use. Ideas for reorganizing, cutting costs, putting in new budgeting systems, improving communication or assembling products in teams are also innovations. Innovation is the generation, acceptance, and implementation of new ideas, processes, products or services" 5 .

The Oslo Manual (OECD 2005') defines innovation as the implementation of a new or significantly improved product (good or service), or process, a new marketing method, or a new organizational method in business practice (where implementation means realization for use).

The term "innovation" is used in many ways to describing both "radical" and complicated technological development processes and minor “incremental” improvements of a company's work processes (as also indicated in the OECD definition above).

\section{Eco-Innovation}

The term Eco-Innovation appears for the first time in literature in the 1990s and has since then been the object of many discussions. Among the more technical issues of the discussion have been:

- should the environmental benefits be the aim of the innovation process in order to fall under the term?

- what level of innovation is required in order to fall under the term?

- and what level of environmental benefits?

- should the environmental angle according to definitions of sustainability be complemented by requirements to social and cultural performance?

The team behind the EU 'Measuring Eco-Innovation Project' defines Eco-Innovation as ${ }^{7}$ :

\footnotetext{
${ }^{3}$ King and Anderson 2002

${ }^{4}$ Michael A. West: "If creativity is the development of new ideas, innovation is the process of actually putting these ideas in to practice”. West, 1997.

${ }^{5}$ Kanter 1983

${ }^{6}$ Oslo Manual for collecting and interpreting innovation data, OECD 2005, Paris.

${ }^{7}$ Kemp et al: Final Report “MEI Project about Measuring Eco-Innovation”, October 2008.
} 
Eco-innovation is the production, assimilation or exploitation of a product, production process, service or management or business method that is novel to the organisation (developing or adopting it) and which results, throughout its life cycle, in a reduction of environmental risk, pollution and other negative impacts of resources use (including energy use) compared to relevant alternatives.

Seeking a more practical formulation the present project defines "EcoInnovation as:

Eco-Innovation

New products and services which, seen in a life cycle perspective, as a result of conscious development cause less environmental impact than comparable products and services.

"Products and services" include development in related services that in total leads to environmental improvements, e.g. more resource efficient distribution or use. Eco-innovative product development can therefore be related to both technological improvement and organisational improvement of products and services and their value chains.

\subsection{Environmental consequences of product development - a case}

For decades it has been acknowledged that product innovation causes consequences - good or bad - for the environment. Whereas some innovative processes have unintentional environmental side effects, other innovative processes are directly destined to develop more environmentally friendly products. The case of computers illustrates the trend that innovation and product development provide environmental benefits.

Computers have gone through a rapid development over the last decade and the environmental impact caused by computers has been reduced significantly per unit.

Environmental challenges associated with computers are to a large extent connected with power consumption, but also contents of hazardous substances and materials and the amount of waste generated call for interest ${ }^{8}$.

Personal computers eligible for the Nordic environmental label, the Swan, are amongst the least environmentally harmful products in their category since they meet strict environmental requirements. A historical screening of criteria from Criteria Version $1.1\left(1995-1998^{9}\right)$ to Version 5.0 (2007-2009) shows important developments and illustrates how the

\footnotetext{
${ }^{8}$ Swan labelling of Personal Computer, Vers. 5.0, Nordic Ecolabelling, 2007

${ }^{9}$ Miljömärkning af persondatorer, Vers 1.1, Nordisk Miljömärkning, 1997
} 
computer as a product has been environmentally improved during these twelve years. Among the important steps forward are:

- The individual computer's power consumption has been reduced radically. In 1995, the Swan allowed an energy consumption of $30 \mathrm{~W}$ (a typical "conventional” computer consumed $120 \mathrm{w}$ ), whereas today it is down to $4 \mathrm{~W}$, giving an improvement of $87 \%$. Similarly the sleep mode power consumption has been reduced by $75 \%$. A rough estimate of the power savings achieved through improved computer technology shows that annual energy savings (2009 compared to 1995) sum up to around 170 GWH (GigaWattHours) per 1 million personal computers. Assuming that the number of computers in the Nordic countries equals the number of people ${ }^{10}$, the energy consumption of the 25,000,000 computers being used in the Nordic countries in 2009 is approximately 4,250 GWH less than compared to 1995 technology.

- Also the content of hazardous substances has developed in an environmentally positive direction. For example, the updated Swan label prohibits the heavy metals of mercury, cadmium and lead in batteries and accumulators in stationary computers, whereas small substances of such substances were allowed in 1995.

\footnotetext{
${ }^{10}$ http://www.electronic-supply.dk/article/view.html?id=24468
} 


\section{International experience with Innovative Green Public Procurement}

\subsection{Innovative Green Public Procurement}

The term Innovative Green Public Procurement (IGGP) is used widely in this project, and comprise all public procurement activities, which seek to stimulate eco-innovation through demands and interaction with suppliers and other stakeholders with the purpose of improving the environmental performance of products and services. Green innovative procurement can be examples of technology procurement as well as pre-commercial procurement or others.

\section{Criteria for Innovative Green Public Procurement}

The following criteria have determined the identification of case-stories as Innovative Green Public Procurement:

1. The products have been through an innovative process leading to a new organizational or technological standard

2. The products have been procured by public institutions

3. The innovative process has provided environmental improvements

4. The supplier(s) is (are) from the private sector

\section{Terminalogy}

There exist a few terms for procurement methodologies, which are usefull to determine in details. In overall the terms is the same but with small technical differencies.

The term "Technology procurement" (widely known in Sweden and US) is a method of merging public procurement with innovation in order to achieve specific benefits (a.o. environmental). Technology procurement is a bidding process that stimulates and enhances the development and market introduction of an article or a service non-existent on the market, requiring development to fulfil the purchaser's objectives and demands. In other words, technology procurement is a markettransformation tool stimulating the development and commercialisation of new products that meet specific functional requirements (e.g. energy efficiency) that are not fulfilled by existing products on the market.

An effective technology procurement process requires that the demanded volume is large enough to stimulate the supplier given the cur- 
rent state of technology, i.e. the bigger the step to be taken, the greater the volume required.

Technology procurement exists in many varieties with some general steps of the process:

- Selection of target areas

- Pre-study or feasibility study

- Creation of a buyer group

- Formulation of specifications

- Tendering process

- Evaluation of tenders

- Spreading of information

- Further development.

The term "pre-commercial procurement" is an EU communication and concerns the Research and Development (R\&D) phase before commercialisation. "Pre-commercial procurement" intended to procure R\&D services. More specifically in pre-commercial procurement:

The scope is $R \& D$ services only: $R \& D$ can cover activities such as solution exploration and design, prototyping, up to the original development of a limited volume of first products or services in the form of a test series. Original development of a first product or service may include limited production or supply in order to incorporate the results of field testing and to demonstrate that the product or service is suitable for production or supply in quantity to acceptable quality standards. R\&D does not include commercial development activities such as quantity production, supply to establish commercial viability or to recover R\&D costs,

The application of risk-benefit sharing: In pre-commercial procurement, the public purchaser does not reserve the R\&D results exclusively for its own use: Public authorities and industry share risks and benefits of the R\&D needed to develop new innovative solutions that outperform those available on the market.

A competitive procurement designed to exclude State aid: Organising the risk/benefit sharing and the entire procurement process in a way that ensures maximum competition, transparency, openness, fairness and pricing at market conditions enables the public purchaser to identify the best possible solutions the market can offer. 


\subsection{Survey of country experience}

A survey of international Innovative Green Public Procurement initiatives has been carried out based on personal contacts to knowledge persons and institutions, review of reports, and information achieved from the internet. A list of references is attached in Appendix 1.

Cases have been identified in twelve countries: Denmark, Finland, France, Germany, The Netherlands, Norway, Portugal, Spain, Sweden, Switzerland and USA.

Table 2.1 below provides an overview of the most interesting international cases identified as "green innovative public procurement". Further details are available in Appendix. 


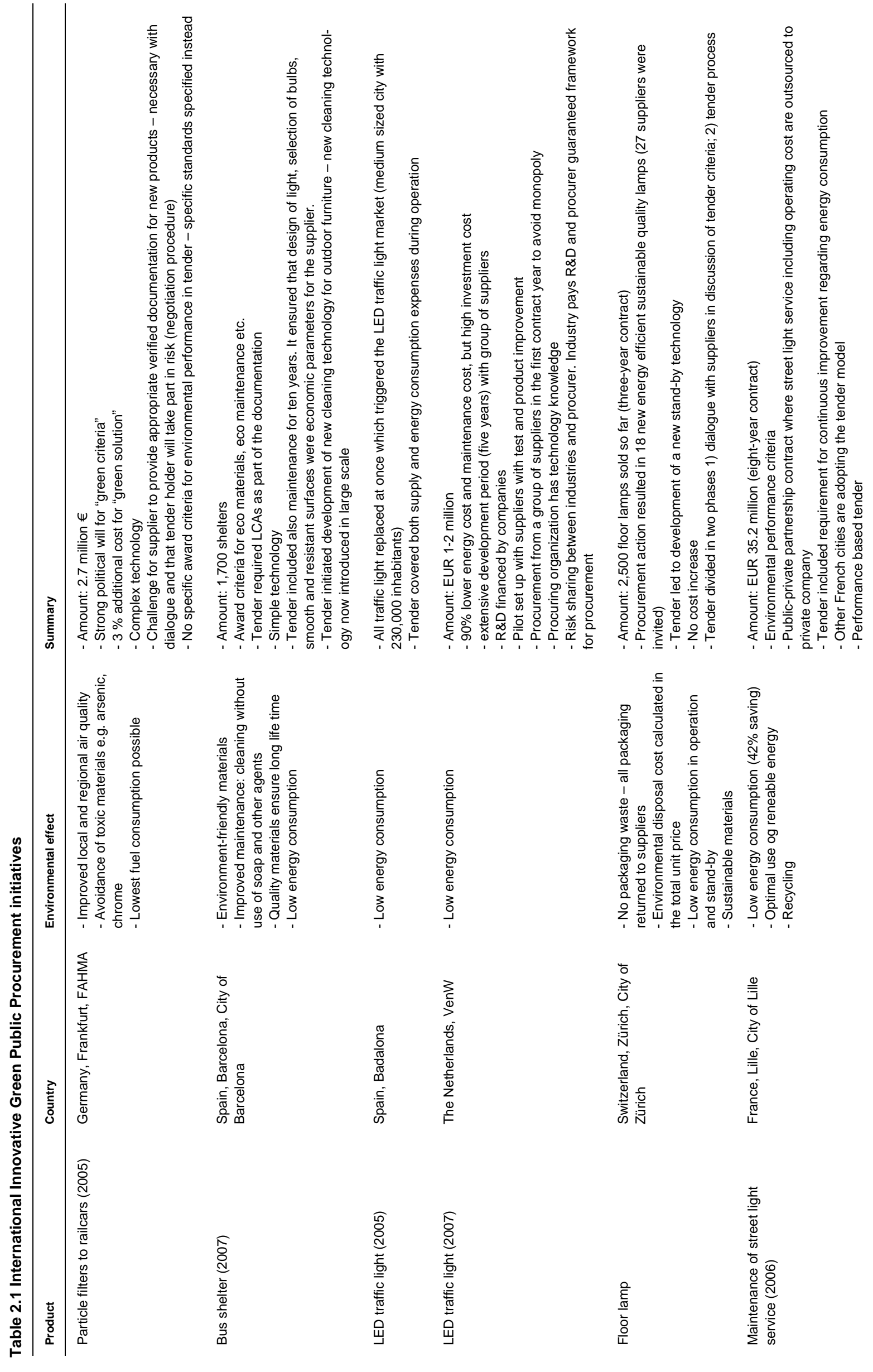




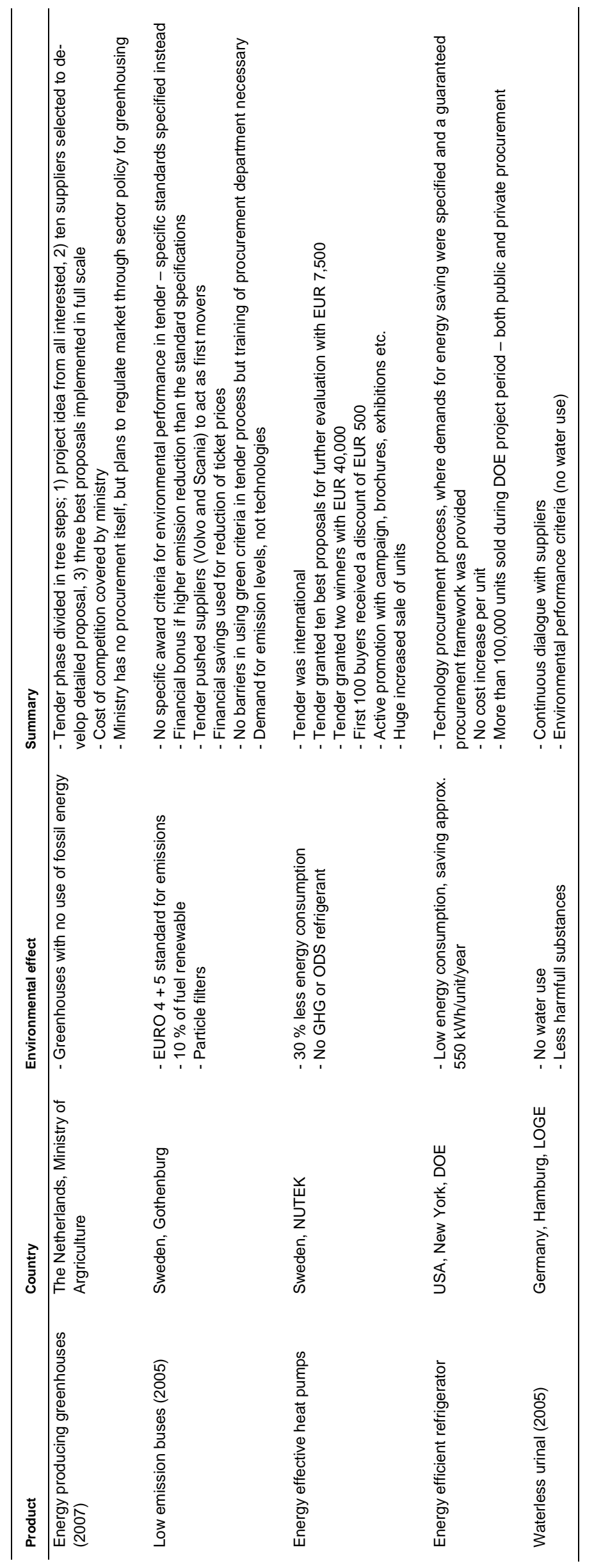


The survey shows the following characteristics:

\section{Energy consuming products}

Most of the screened cases in this survey concern energy consuming products with a clear cost saving potential and therefore high motivation for product improvement.

\section{Long operational time}

Product innovation often leads to improved operation and maintenance of the products and all the products from this survey are characterized by a long operational life.

\section{Tender criteria}

Three types of tender criteria have been identified:

- criteria based on specific technical standards concerning, e.g., emissions. These criteria require considerable technical knowledge from the public procurement institution.

- criteria concerning environmental performance, e.g. recycling, continuous improvement etc. These criteria require less technical knowledge and are easier to use in the tender process than the above mentioned criteria, and further offer a larger "innovative space" for the supplier.

- criteria concerning price per unit, including operation and disposal cost for the product (typically supplementing other criteria).

None of the screened cases have used technology criteria.

\section{Risk sharing}

All cases make use of some kind of risk sharing, typically:

- The supplier covers own research and development cost

- The procurement body provides a framework contract for procurement and is willing to test and buy products without the traditional standard documentation and product guarantees.

It is of major importance that the procurement body is motivated for a dialogue with suppliers concerning solutions and documentation need.

\section{Financial cost}

All screened products, apart from one, have equivalent or lower costs in the life cycle perspective due to operational savings, and most products also have a cost saving potential at the medium term perspective. 
Spin off

In most cases, the tender process has led to development of new technologies that were introduced immediately on the market with commercial success, e.g. the stand-by technology (floor lamps), EURO 5 particle filters (railcars) and cleaning method for outdoor furniture (bus shelters). This experience indicates that suppliers will achieve commercial benefits from taking part in an innovative tender process.

In cases with open competition several suppliers have benefittted from the development process, e.g. the case with greenhouses and the case with LED street lightning.

\section{Tender model}

The following tender models have been used:

Competition: The tender is structured as an open competition, where interested suppliers can submit project ideas. A group of winners is selected for more detailed proposals and finally a few winners are invited to develop in full scale.

Two step tender: The tender can be open or closed. Suppliers are invited to a close dialogue concerning the tender criteria and then an ordinary tender process takes place.

None of the screened cases have used a traditional tender process with clearly defined criteria and selection. All cases have involved discussions and development of ideas in a dialogue between the parties. It appears that dialogue is a necessary driver for having suppliers taking actively part in this kind of product development.

\subsection{Specific IGPP initiatives of interest}

The most interesting international initiatives include:

Germany $^{11}$

In Germany a political step forward has been taken to reinforce innovative development of products and services. Six ministries, including the Ministry of Environment, have signed a common declaration on intensifying innovative procurement in the public sector.

The declaration does not have a declared environmental focal point but takes the first step on opening up to public demand for innovative solutions. So far, public sectors all over Europe have traditionally been reluctant to do so, because of the economic risks it might include.

\footnotetext{
${ }^{11}$ http://www.beschaffnginfo.de/
} 
SMART SPP - innovation through sustainable procurement

SMART SPP is a European project which will promote the introduction of new, innovative low carbon emission technologies and integrated solutions onto the European market. This will be done by encouraging early market engagement between public authority procurers and suppliers and developers of new innovative products and services in the preprocurement phase of public tenders.

The project is supported by the Intelligent Energy Europe funding programme. It is a multi-partner initiative which involves experts from organisations across Europe and ICLEI is lead partner.

The project will specifically focus on the following products and services:

- Lighting systems (e.g. LED lighting, OLED-lighting, lighting tubes),

- Highly energy efficient (electric) vehicles (passenger and duty cars), and

- Construction services (e.g. heating/cooling systems using renewable energy sources

SMART SPP will develop a standard approach to pre-procurement of emerging technologies. The approach will include managing the risks in pre-procurement, assessing the financial benefits (life-cycle costing), and calculating and communicating the $\mathrm{CO}_{2}$ savings. Existing best practice in the field of pre-procurement, legal considerations and appropriate solutions, technologies and suppliers to involve in the project will be explored. Tools, tender documents, manuals and training sessions will also be developed to assist in building the capacity of public authorities who wish to use pre-procurement to purchase emerging technologies.

\section{EU Energy+}

The Energy ${ }^{+}$procurement project was conducted under the auspices of the SAVE Programme of the European Commission. The Energy+ steering group was composed of representatives from the European Commission and thirteen national agencies. The project ended in 2004.

The goal of Energy+ was to reinforce the emerging trend towards energy efficiency on domestic markets. Addressing both the supply and the demand side, Energy+ created significant appliances markets for existing products with good qualities and at the same time speeded up the introduction of new technologies. Qualifying appliances were very scarce at the start of the project in 2000, but four years later the Energy+ success was materialised by a list of almost 900 models from several manufacturing groups complying with the new Class A+ and A++ of the European Energy Label.

Energy+ achievements show that actions organised by governments can be effectively combined with individual and corporate environmentfriendly awareness to contribute to the reduction of carbon dioxide emissions thanks to energy-savings. 


\section{ICLEI $^{12}$ (International Council for Local Environmental Initiatives)}

Public Procurement Boosts Energy Efficiency (PRO-EE) (2007 - 2010). The project aims to harness the buying power of public authorities to drive the market for innovative environmental technologies. A partnership of public authorities from six European countries will undertake large-scale joint procurement of technologies to secure a higher market share for the most energy efficient products to accelerate their market penetration.

PRO-EE will work on innovative products for which the economic and technical energy saving potential is high in comparison to actual products available on the market. Examples include more energy efficient office equipment, energy saving streetlights, traffic lights and fuel efficient vehicles. The public authorities involved shall push new environmental technologies, and by this contribute to strengthening the competitiveness of European industries.

PRO-EE shall bring together the producer and the consumer side to share the risks and the benefits of pursuing novel services and products: They will work together continuously, define the priorities jointly, agree on concrete products and their criteria for being purchased and by this, foster the innovation process. The project will set up a partnership between market actors in six European countries to develop innovative approaches for public authorities and, by this to influence the supplier side of energy efficient products and services.

Regional sub-networks will be established which are assisted by national expert organisations. They provide practical and technical advice to the authorities through a step-by-step training and implementation approach.

EU Guide on dealing with innovative solutions in public procurement

This guide focuses on public procurement as part of a broader innovation strategy and explains how public procurement can motivate innovation. It complements previous and ongoing efforts to promote environmental technologies through public procurement procedures. Further actions will follow in order to address the still unexploited opportunities in Europe for procurement of $R \& D$ services, where benefits and costs are shared between the public authorities and the suppliers (i.e. precommercial procurement).

Applying the rules of the procurement framework correctly and making use of the flexibility they offer will make it possible to achieve more innovative solutions. The new procurement directives offer more opportunities for government purchasers to use innovation-oriented tendering.

This guide provides supportive elements for decision makers who want to develop and implement a public procurement policy that promotes innovation. It builds upon concrete examples that have been identified by practitioners and widely discussed with public and private experts. They reflect the current state of information on public procurement

\footnotetext{
${ }^{12}$ http://www.iclei-europe.org
} 
practices within the EU Member States that need to be adapted to national and local conditions by the relevant authorities at that level and to be implemented accordingly. In this respect, this guide should be considered only as a first step towards more favourable conditions for innovation through public procurement, requiring a continuous exchange of practical experience and full political commitment.

\section{EU Green Public Procurement toolkit}

GPP Training Toolkit designed for use by green public procurement trainers or for integration in general public procurement training courses. The toolkit consists of three independent modules, each designed to overcome a specific problem identified as a barrier to the uptake of Green Public Procurement within a public organisation:

- a strategic module which seeks to raise the political support for green public procurement within an organisation, targeting in particular decision makers

- a legal module which seeks to clarify legal issues and is designed for both strategic and operational levels

- an operational module aimed at purchasing officers, responsible for the preparation of tender documents; includes concrete examples of environmental criteria for eleven product and service groups, for use in public tendering procedures.

The final report of the Green Public Procurement in Europe study provides conclusions and recommendations for organisations and individuals working on national GPP action plans of Member States, as well as for purchasers and other stakeholders in the operational procurement process. The implementation of these recommendations is designed to enhance the quantity and quality of GPP in Europe.

The EU has initiated specific programmes to promote demand side innovation, including eco-innovation. Of particular note are:

- The Lead Market Initiative (LMI) launched in 2006 to give industries the opportunity to develop niche markets into export products or services in new high-growth markets.

- A "pre-commercial procurement" policy to encourage public procurers to share the risk (and reward) of developing and commercialising innovations which fit their needs.

- The Environmental Technologies Action Plan (ETAP) which recognises the importance of improving market conditions. 


\section{Assessment of product and service groups in public procurement}

This chapter presents the methodology and results of a process leading to selection of a limited number of important product groups with a considerable environmental impact in Nordic public procurement.

The methodology has been:

- Quantification of the ten largest (in terms of purchase price) product groups (NACE code level 1) in the Nordic countries and detailing of the NACE level 1 product groups into NACE code level 2.

- Correlation of the identified largest product groups with an EU study of the environmentally most important product groups, identification of the environmentally most important sub product groups in Nordic public procurement.

- Correlation to EU studies on most relevant product groups for European green public procurement.

- Analysis of the potential for innovation and environmental development of the environmentally most important product groups and selection of three product groups for further investigations.

\subsection{Main product groups in Nordic public procurement}

Eurostat input-output data are produced with uniform methods all over Europe and are - among others - used for studying structural changes in national economies and evaluating the impact of the changes on e.g. production, imports, inflation and employment. The input-output tables also provide information on the industrial sectors' input to the public sectors.

In order to analyse Nordic public procurement, input-output tables have been compiled from Denmark, Norway, Finland and Sweden. At the moment Department for National Accounts in Statistics Iceland is preparing data that are comparable with the input-output table ${ }^{13}$.

\footnotetext{
${ }^{13}$ Another methodology is to compile data from the national public procurement organisations. A screening of such data showed a lack of transparency in methods and types of data that made it impossible to gain a reliable and comparable picture of total public procurement in the Nordic countries.
} 
The national input-output tables are divided into 59 product groups (referring to the NACE codes ${ }^{14}$ ) such as agriculture, textiles, post and telecommunication, construction work and public administration. Relevant groups with connection to public procurement have been identified in close cooperation with the Danish and Swedish statistical bureaus ${ }^{15}$. For each country, the ten most important product groups in financial terms have been identified as shown in tables $2.2-2.5$ below $^{16}$.

Table 3.1 The ten largest groups in public procurement in Sweden

\begin{tabular}{lrrrr}
\hline & $\begin{array}{r}\text { Million } \\
\text { Euro }\end{array}$ & $\begin{array}{r}\text { Euro } \\
\text { per } \\
\text { capita }\end{array}$ & $\begin{array}{r}\text { Part of } \\
\text { national } \\
\text { input (\%) }\end{array}$ \\
\hline Total & 28622 & 100 & 3216 & 12 \\
Real estate services & 5953 & 21 & 669 & 41 \\
Other business services & 3527 & 12 & 396 & 11 \\
Trade, maintenance and repair services of motor vehicles & 1607 & 6 & 181 & 12 \\
and motorcycles; retail sale of automotive fuel & & & & \\
Public administration and defence services; compulsory & 1596 & 6 & 179 & 55 \\
social security services & & & & 152 \\
Post and telecommunication services & 1351 & 5 & 152 & 18 \\
Construction work & 1118 & 4 & 126 & 15 \\
Printed matter and recorded media & 1019 & 4 & 114 & 15 \\
Land transport; transport via pipeline services & 900 & 3 & 101 & 9 \\
Medical, precision and optical instruments, watches and & 824 & 3 & 93 & 37 \\
clocks & & & & 63 \\
Health and social work services & 716 & 2 & 80 & \\
\hline
\end{tabular}

Table 3.2 The ten largest groups in public procurement in Denmark

\begin{tabular}{lrrrr}
\hline & $\begin{array}{r}\text { Million } \\
\text { Euro }\end{array}$ & $\begin{array}{r}\text { Euro } \\
\text { per } \\
\text { capita }\end{array}$ & $\begin{array}{r}\text { Part of } \\
\text { national } \\
\text { input (\%) }\end{array}$ \\
\hline Denmark & & & & \\
Total & 18318 & 100 & 3392 & 12 \\
Other business services & 2372 & 13 & 439 & 14 \\
Computer and related services & 1213 & 7 & 225 & 30 \\
Post and telecommunication services & 1207 & 7 & 224 & 19 \\
Recreational, cultural and sporting services & 1204 & 7 & 223 & 57 \\
Real estate services & 1077 & 6 & 199 & 19 \\
Land transport; transport via pipeline services & 1016 & 6 & 188 & 17 \\
Construction work & 940 & 5 & 174 & 14 \\
Sewage and refuse disposal services, sanitation and similar & & & & \\
services & 799 & 4 & 148 & 54 \\
Public administration and defence services; compulsory & & & & \\
social security services & 668 & 4 & 124 & 44 \\
Chemicals, chemical products and man-made fibres & 614 & 3 & 114 & 13 \\
\hline
\end{tabular}

${ }^{14}$ NACE codes are used to statistically classify economic activities within the European Community according to Commission Regulation 29/2002 (Rev. 1.1). A new version Rev. 2 exists but Rev 1.1 matches the data collected.

${ }^{15}$ Peter Rørmose Jensen, Statistics Denmark, April and May 2008; Katarina Johansson, Statistics Sweden, May 2008

${ }^{16}$ Tables 2.2-2.5 The 10 largest groups in public procurement in four Nordic countries, economic value. Based on Eurostat data: http://epp.eurostat.ec.europa.eu. Product groups according to NACE level 1. 
Table 3.3 The ten largest groups in public procurement in Norway

\begin{tabular}{lrrrr}
\hline & $\begin{array}{r}\text { Million } \\
\text { Euro }\end{array}$ & $\begin{array}{r}\text { \% } \\
\text { Euro } \\
\text { per } \\
\text { capita }\end{array}$ & $\begin{array}{r}\text { Part of } \\
\text { national } \\
\text { input (\%) }\end{array}$ \\
\hline Total & 15541 & 100 & 3454 & 10 \\
Construction work & 2068 & 13 & 460 & 22 \\
Other business services & 2006 & 13 & 446 & 14 \\
Printed matter and recorded media & 846 & 5 & 188 & 20 \\
Real estate services & 833 & 5 & 185 & 14 \\
Post and telecommunication services & 694 & 4 & 154 & 9 \\
Computer and related services & 681 & 4 & 151 & 14 \\
Wholesale trade and commission trade services, except of & & & & 9 \\
motor vehicles and motorcycles & 608 & 4 & 135 & 13 \\
Chemicals, chemical products and man-made fibres & 541 & 3 & 120 & 12 \\
Machinery and equipment n.e.c. & 458 & 3 & 102 & 15 \\
Hotel and restaurant services & 444 & 3 & 99 & \\
\hline
\end{tabular}

Table 3.4 The ten largest groups in public procurement in Finland

\begin{tabular}{lrrrr}
\hline & $\begin{array}{r}\text { Million } \\
\text { Euro }\end{array}$ & $\begin{array}{r}\text { \% } \\
\text { Euro } \\
\text { per } \\
\text { capita }\end{array}$ & $\begin{array}{r}\text { Part of } \\
\text { national } \\
\text { input (\%) }\end{array}$ \\
\hline Total & 15226 & 100 & 2873 & 11 \\
Other business services & 1718 & 11 & 324 & 15 \\
Wholesale trade and commission trade services, except of & & & & \\
motor vehicles and motorcycles & 1439 & 9 & 272 & 15 \\
Real estate services & 1078 & 7 & 203 & 26 \\
Health and social work services & 913 & 6 & 172 & 82 \\
Post and telecommunication services & 782 & 5 & 147 & 16 \\
Hotel and restaurant services & 750 & 5 & 142 & 40 \\
Chemicals, chemical products and man-made fibres & 734 & 5 & 138 & 12 \\
Electrical energy, gas, steam and hot water & 697 & 5 & 131 & 15 \\
Printed matter and recorded media & 625 & 4 & 118 & 20 \\
Land transport; transport via pipeline services & 506 & 3 & 95 & 10 \\
\hline
\end{tabular}

Table 3.5 Accumulated public procurement in the four Nordic countries

\begin{tabular}{lr}
\hline Nordic public procurement (million Euro) & Million \\
\hline Industrial sector (NACE code) & Euro \\
\hline Other business services & 10879 \\
Real estate services & 9386 \\
Construction work & 5580 \\
Post and telecommunication services & 4466 \\
Computer and related services & 3538 \\
Printed matter and recorded media & 3291 \\
Land transport; transport via pipeline services & 3135 \\
Wholesale trade and commission trade services, except of motor vehicles and motorcycles & 3020 \\
Public administration and defence services; compulsory social security services & 2946 \\
Chemicals, chemical products and man-made fibres & 2799 \\
Recreational, cultural and sporting services & 2569 \\
Electrical energy, gas, steam and hot water & 2560 \\
Hotel and restaurant services & 2468 \\
Trade, maintenance and repair services of motor vehicles and motorcycles; retail sale of & 2314 \\
automotive fuel & 2073 \\
Health and social work services & 1760 \\
Financial intermediation services, except insurance and pension funding services & 1736 \\
Machinery and equipment n.e.c. & 1635 \\
Food products and beverages & \\
\hline
\end{tabular}

Source, Based on Eurostat data: http://epp.eurostat.ec.europa.eu. 
In order to enable a more focused assessment of the innovation potential within product groups the above product lists at a generic level (NACE code level 1) are detailed at NACE level 2. This detailing is based on Danish studies of public procurement ${ }^{17}$. All product groups at the Nordic NACE level 1 list (table 2.6) are included in the Danish study ${ }^{18}$.

Table 3.6 The most important sub product groups in Nordic PP

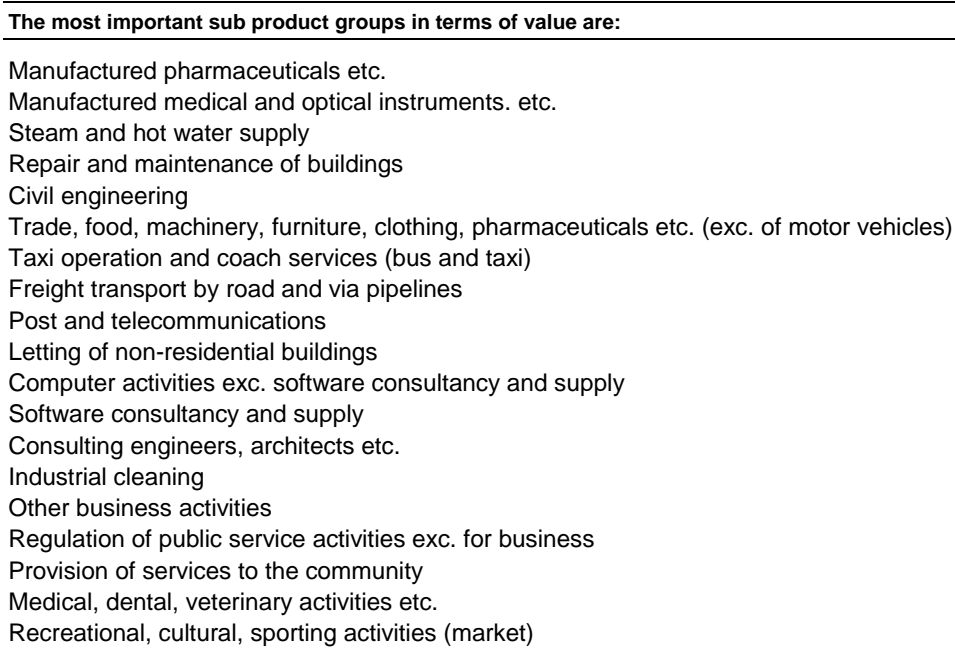

\subsection{Environmentally important products in PP}

A number of research reports and analyses deal with the question of identifying the most environmentally important products and services in a European context. As these comprehensive and time consuming analyses have been carried relatively recently, the present project will lean on these in the identification of the most environmentally important product groups in Nordic public procurement.

\section{EU input/output analysis}

A recent environmental input-output analysis for EU-25 on eight environmental impact categories concludes that $20 \%$ of the product groups account for $80 \%$ of the environmental impact and $7 \%$ of the product groups for $50 \%$ of the impact ${ }^{19}$.

${ }^{17}$ Peter Rørmose, Statistics Denmark, 2008. For each Level 1 group the most important subgroups have been identified and the procurement value calculated.

${ }^{18}$ Based on data from Peter Rørmose, Statistics Denmark, 2008.

${ }^{19}$ Environmental Impact of Products (EIPRO), Analysis of the life cycle environmental impacts related to the final consumption of the EU-25, Main Report, IPTS/ESTO project, Arnold Tukker et al. May 2006. 
Table 3.7 The environmentally most important product groups in Europe

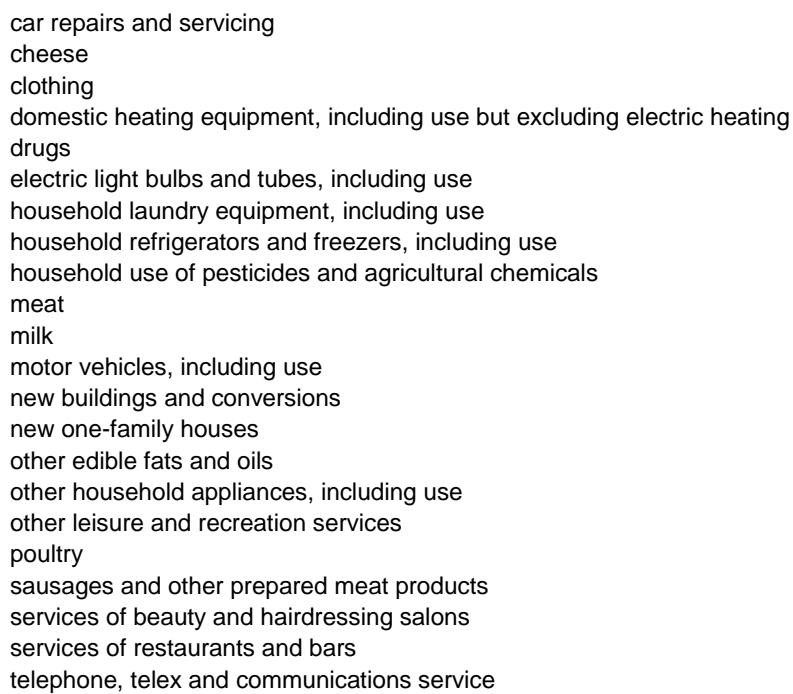

A correlation of the list of economically important products (section 2.1) and the environmentally most important products groups (above) provides the following list of the seven most important product groups in Nordic Public Procurement in terms of environment and economy:

Table 3.8 The environmentally and economically most important product groups in Nordic PP

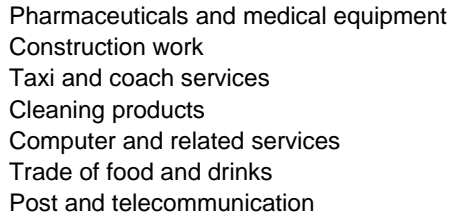

All of the seven product groups and services have a high public procurement volume and in principle a considerable potential for environmental improvement.

\subsection{Selection of eco-innovative product groups}

\section{Correlation with other studies}

Two European initiatives provide the opportunity of testing the above list with a selection of products deemed important in a European GPP context. 


\section{EU Green Public Procurement strategy}

The EU Commission has developed toolkits for public purchasers for "greening" of the procurement. Criteria have been established for eleven product and service groups with:

- important environmental impact and/or

- potential for environmental improvement and/or

- financial impact and/or

- political or example-setting function.

The eleven groups are:

- Paper

- Cleaning product

- Office machinery

- Construction

- Transport

- Furniture

- Electricity

- Food and Catering services

- Textiles

- Gardening services

- Equipment used in the health sector (documents will be published in due course)

\section{EU Quantitative GPP indicators}

An ongoing European survey is establishing methodologies for calculating quantitative indicators on Green Public Procurement (GPP) ${ }^{20}$ with focus on ten priority product groups, based on:

- procurement value

- availability of green criteria

- EC priority (eleven priority groups used for GPP toolkit criteria)

- relevance for public institutions and

- environmental impact.

\footnotetext{
${ }^{20}$ (www.thevalueofgreen.com)
} 
The following products/product groups are pointed out as especially important:

- Cleaning services

- New building \& Offices

- Electricity

- Catering Services

- Gardening

- Computers \& Monitors

- Paper

- Clothing

- Passenger cars and light duty vehicles

- Office furniture

The European surveys agree on five of the product groups identified as important in a Nordic context: Pharmaceuticals and post \& telecommunication are not selected as relevant in the European GPP context.

In order to select three product groups for further investigation, an analysis of the perspectives for environmental development and innovation have been performed on the seven product categories identified as specifically environmentally important in Nordic public procurement. 
Table 3.9 Screening of environmental and innovative aspects of product groups

\begin{tabular}{|c|c|c|c|}
\hline Product group & Environment & Innovation & Notes \\
\hline $\begin{array}{l}\text { Pharma and } \\
\text { medical } \\
\text { equipment }\end{array}$ & $\begin{array}{l}\text { MED: energy consumption, } \\
\text { packaging, use of materials } \\
\text { (plastics and metals)...large } \\
\text { and differentiated product } \\
\text { group } \\
\text { PHARM: wastewater, packag- } \\
\text { ing waste } \\
\text { General remark - product } \\
\text { group regulated in detail } \\
\text { through health and safety } \\
\text { requirements. Pharma pro- } \\
\text { duced by global companies }\end{array}$ & $\begin{array}{l}\text { Long history of } \\
\text { continuous innova- } \\
\text { tion. } \\
\text { MED: composition of } \\
\text { sustainable materials, } \\
\text { risk reduction due to } \\
\text { end of life, reduction of } \\
\text { energy consumption - } \\
\text { stand-by + operation } \\
\text { PHARM: sustainable } \\
\text { packaging }\end{array}$ & $\begin{array}{l}\text { Pharma and medical equip- } \\
\text { ment is in general a very } \\
\text { complex product group and } \\
\text { operated with many de- } \\
\text { mands and a regulatory } \\
\text { framework related to health- } \\
\text { care issues. } \\
\text { Does not appear on Euro- } \\
\text { pean lists. }\end{array}$ \\
\hline $\begin{array}{l}\text { Construction } \\
\text { work }\end{array}$ & $\begin{array}{l}\text { Sustainable building materials, } \\
\text { renewable energy sources, } \\
\text { green tech - pumps, sanitary, } \\
\text { supply, electricity etc. } \\
\text { Sustainable operation - low } \\
\text { energy consumption, reduced } \\
\text { waste generation.. } \\
\text { Sustainable construc- } \\
\text { tion/service. Use of environ- } \\
\text { mentally friendly methods and } \\
\text { chemicals, optimized logistics } \\
\text { and material supply etc. }\end{array}$ & $\begin{array}{l}\text { Large potential - } \\
\text { building materials, } \\
\text { construction tech- } \\
\text { niques, energy con- } \\
\text { sumption during life } \\
\text { time, improvement of } \\
\text { services, savings } \\
\text { during operation } \\
\text { Developed market }\end{array}$ & \\
\hline $\begin{array}{l}\text { Taxi and } \\
\text { coach ser- } \\
\text { vices }\end{array}$ & $\begin{array}{l}\text { Energy saving, reduced } \\
\text { emissions of } \mathrm{CO}_{2} \text {, particles, } \\
\text { VOC, } \mathrm{NOx}\left(\text { and } \mathrm{SO}_{2} \text { ), reduc- }\right. \\
\text { tion of health risk }\end{array}$ & $\begin{array}{l}\text { Innovation moving } \\
\text { towards electric cars. } \\
\text { Influenced by devel- } \\
\text { opment of infrastruc- } \\
\text { ture. } \\
\text { Better emission } \\
\text { performance }\end{array}$ & \\
\hline $\begin{array}{l}\text { Cleaning } \\
\text { products }\end{array}$ & $\begin{array}{l}\text { Chemicals/detergent in } \\
\text { wastewater, health and safety, } \\
\text { water consumption }\end{array}$ & $\begin{array}{l}\text { Improving detergent } \\
\text { performance. Improv- } \\
\text { ing cleaning technol- } \\
\text { ogy. }\end{array}$ & $\begin{array}{l}\text { Cleaning products is an } \\
\text { interesting group in an eco- } \\
\text { innovative perspective, but } \\
\text { very much depended on de- } \\
\text { velopment in basic chemicals. }\end{array}$ \\
\hline $\begin{array}{l}\text { Computers } \\
\text { and related } \\
\text { services }\end{array}$ & $\begin{array}{l}\text { Energy consumption from } \\
\text { equipment, sustainable mate- } \\
\text { rials, waste reduction } \\
\text { (WEEE/RoHS) }\end{array}$ & $\begin{array}{l}\text { Improved energy } \\
\text { saving, use of sus- } \\
\text { tainable materials, } \\
\text { improved packaging, } \\
\text { no flame retardants, } \\
\text { heavy metals etc, } \\
\text { improved recycling } \\
\text { Developed market }\end{array}$ & \\
\hline $\begin{array}{l}\text { Trade of food } \\
\text { and drinks }\end{array}$ & $\begin{array}{l}\text { Packaging, production, chemi- } \\
\text { cals, health, transport }\end{array}$ & $\begin{array}{l}\text { Organic production of } \\
\text { basic food, improved } \\
\text { packaging, }\end{array}$ & $\begin{array}{l}\text { Trade of food and drinks in an } \\
\text { eco-innovative perspective is } \\
\text { considered to be efforts in re- } \\
\text { lation to organic food, logistic } \\
\text { and packaging. The product } \\
\text { group is not selected because } \\
\text { innovation potentials seem } \\
\text { relatively simple and e.g. trans- } \\
\text { port will be covered partly in } \\
\text { the "taxi and coach service } \\
\text { group". }\end{array}$ \\
\hline $\begin{array}{l}\text { Post and } \\
\text { telecommuni- } \\
\text { cation }\end{array}$ & $\begin{array}{l}\text { Emission from transport and } \\
\text { service }\end{array}$ & $\begin{array}{l}\text { Improved logistics, } \\
\text { sustainable vehicles }\end{array}$ & $\begin{array}{l}\text { Post and telecommunication is } \\
\text { partly covered by "IT product } \\
\text { and service" and "Taxi and } \\
\text { coach service". Does not } \\
\text { appear on European lists. }\end{array}$ \\
\hline
\end{tabular}


From this initial screening three product groups can be identified as especially relevant for an analysis of the potential benefits and challenges of IGPP:

- Construction work

- Computers and related services

- Taxi and bus services 



\section{Investigation of eco-innovative potentials}

In this phase, the eco-innovative potentials for the three selected product groups (section 3) are investigated in a Nordic context through a desk study and a series of interviews with key stakeholders in the Nordic countries. The purpose is to form a picture of the potential environmental benefits that can be achieved in the Nordic countries through IGPP.

The three product groups are:

- Construction work

- IT products and related services

- Taxi and bus services

The survey includes:

- Identification of the eco-innovative potential of each product group

- Estimates of environmental effects

- Relevant incentives for stimulating eco-innovation through public procurement

- Barriers for exploiting the eco-innovation potential

- Input to strategies for innovative green public procurement

The interview survey have been carried out by national consultants in Denmark, Finland, Norway and Sweden with the following division of product groups:

Table 4.1 National surveys of eco-innovative potentials

\begin{tabular}{lcccc}
\hline & Denmark & Finland & Norway & Sweden \\
\hline Construction work & $\mathrm{X}$ & & & $\mathrm{X}$ \\
IT products and related services & $\mathrm{X}$ & & $\mathrm{X}$ & \\
Taxi and coach services & $\mathrm{X}$ & $\mathrm{X}$ & & \\
\hline
\end{tabular}

\subsection{Methodology}

The national consultants have examined existing studies and carried out a series of interviews with key persons from industry organisations, central manufacturers/suppliers, and other relevant stakeholders. The interviews with selected key persons embraced, but were not delimited to, the following questions: 
Table 4.2 Questionnaire

\begin{tabular}{|c|c|}
\hline Topic for assessment & Areas of interest \\
\hline $\begin{array}{l}\text { Identification of innovation potential } \\
\text { of product group }\end{array}$ & $\begin{array}{l}\text { - draft the value chain } \\
\text { - identify central actors for product development in the value } \\
\text { - chain } \\
\text { - define the market - low cost, quality, service, ... } \\
\text { - identify historical experience with innovation in the Nordic } \\
\text { countries and internationally } \\
\text { - identify organisational parameters relevant for the innova- } \\
\text { tion potential } \\
\text { - identify policy elements, networks and other parameters } \\
\text { relevant for the innovation potential } \\
\text { - visions, thoughts and plans for innovation within the prod- } \\
\text { uct area }\end{array}$ \\
\hline $\begin{array}{l}\text { Likelihood that Nordic public procur- } \\
\text { ers can influence manufacturers' } \\
\text { efforts }\end{array}$ & $\begin{array}{l}\text { sector with large or small enterprises } \\
\text { global/local market } \\
\text { dependency of suppliers or dependency of customers }\end{array}$ \\
\hline $\begin{array}{l}\text { Screening of environmental benefits } \\
\text { achievable from eco-innovation }\end{array}$ & $\begin{array}{l}\text { energy } \\
\text { resources } \\
\text { waste } \\
\text { cleaner technology } \\
\text { hazardous substances } \\
\text { packaging, transportation etc. }\end{array}$ \\
\hline $\begin{array}{l}\text { Incentives for eco-innovative product } \\
\text { development }\end{array}$ & $\begin{array}{l}\text { market demand, including expectations } \\
R \& D \\
\text { regulation, legislation }\end{array}$ \\
\hline $\begin{array}{l}\text { Need for technological and other } \\
\text { consultancy }\end{array}$ & $\begin{array}{l}\text { materials } \\
\text { process technology } \\
\text { market development }\end{array}$ \\
\hline Barriers for eco-innovation & $\begin{array}{l}\text { regulation } \\
\text { price } \\
\text { market and demand } \\
\text { competition } \\
\text { lack of R\&D, consultancy }\end{array}$ \\
\hline Elements of strategy & $\begin{array}{l}\text { Considerations } \\
\text { elements and strategy components }\end{array}$ \\
\hline
\end{tabular}

The work plan has followed similar paths in the four countries:

- Definition and delimitation of the product group. This is an iterative process as handling of gathered data will create new insights and potentially a need for revision of the product group definition.

- Identification of environmental and innovation parameters. This is also an iterative process as handling of gathered data may create new insights and potentially a need for revision of the list of environmental parameters.

- Gathering of data for innovation potential through literature review and interviews with sector organisations, universities, technological institutes, knowledge persons, and at least one enterprise:

- Technological eco-innovative options in a life cycle perspective (potential technical improvements, process improvements, ...)

- Organisational eco-innovative elements in a life cycle perspective (education level, networks, innovation strategies, ...) 
- Estimate of market share for new technology (if any). We set a minimum limit for market share as part of the definition that a product has eco-innovative potential

- Incentives, barriers, utilisation of potentials etc.

- Assess the potential environmental benefits and innovation costs

\subsection{Construction work}

Construction work constitutes a very broad range of products and services such as:

- construction of buildings

- demolition of buildings

- soil removal

- civil engineering works

- construction of infrastructure

- handicraft services

The analysis has been limited to the dominating sub-sector "construction of buildings" in order to enable a deeper analysis, in the following named "the building sector".

\subsubsection{Key characteristics of the building sector}

The building sectors in the Nordic countries have many similarities in terms of structure, value chain, and organisation of the sector with important key characteristics in relation to eco-innovation:

- The building sector operates in a local market with local standards, legislation and cultures. Even globally leading contractors have to act locally and respond to local demands. The Nordic building sector is characterised by high quality.

- The sector is strongly project oriented. If the client is not proactive and demanding it is difficult to implement innovations. The project oriented approach involves many relations to sub suppliers etc. and the value chain changes from project to project which may be a weakness in relation to innovation and development of competences.

- As the financial source the building owner has $100 \%$ power to ensure specifications implemented in the constructions but the building owner is in general technically weak.

- Key stakeholders are contractors, architects and engineers, of which especially the two latter groups constitute the key to development and diffusion of eco-innovative solutions. 
- The sector is characterized by large companies dominating the market and a multitude of small companies.

- The contractor is responsible for quality of the construction and purchases building materials and equipment according to internal procedures. If the owner stipulates specific (e.g., environmental) requirements for materials this may cause problems in terms of defining the responsibility of the total construction work.

- Building material suppliers are often quite innovative. The sector is known for providing quick response and adapt to new realities and standards from project to project.

- Most building contracts are based on tenders with a dominating focus on price. Profit margin is typically low and the risk factor high. A few mistakes or delays can outbalance the entire profit margin.

- The building sector is also project oriented. Each project creates unique possibilities and problems. Many experiments are made, but they are not spread systematically.

\subsubsection{Eco-innovative potential}

Construction of new buildings has extensive potential for eco-innovation and numerous actors have implemented a vast number of visionary elements and eco-innovative technologies in individual buildings. Renovation projects also contain potentials for eco-innovative improvement, but in a smaller scale.

Studies from Sweden indicate that construction and housing stands for totally approx. $40 \%$ of the material consumption and $40 \%$ of the energy consumption in Sweden. Nordic Council of Ministers discuss potentials in a report on energyefficiency in the Nordic building sector ${ }^{21}$.

Table 4.3 presents a number of relevant eco-innovative solutions identified during the national surveys. The environmental effect of the solutions is mainly related to energy savings during the life time of the building, saving of resources to production of building materials, reduction of construction waste, and reduced consumption of toxic materials.

\footnotetext{
${ }^{21}$ Energy efficiency in the Nordic building sector, 2009
} 
Table 4.3 Potential eco-innovative solutions related to construction of buildings

\begin{tabular}{|c|c|}
\hline Eco-innovative solutions & Innovative and environmental effect \\
\hline $\begin{array}{l}\text { Low energy houses (insulation, venti- } \\
\text { lation, energy sources etc.) }\end{array}$ & $\begin{array}{l}\text { Energy savings up to } 80 \% \text {. Reduction of } \mathrm{CO}_{2}, \mathrm{SO}_{2}, \mathrm{NOx} \\
\text { and energy resources }\end{array}$ \\
\hline Energy control systems in buildings & $\begin{array}{l}\text { Energy saving. Reduction of } \mathrm{CO}_{2}, \mathrm{SO}_{2}, \mathrm{NOx} \text { and energy } \\
\text { resources }\end{array}$ \\
\hline Sustainable sewage systems & $\begin{array}{l}\text { Depending on design it has impact on municipal sewage } \\
\text { infrastructure }\end{array}$ \\
\hline Water saving supply systems & $\begin{array}{l}\text { Water saving relevant in areas, where water is a limited } \\
\text { resource }\end{array}$ \\
\hline Light system & $\begin{array}{l}\text { Energy saving. Reduction of } \mathrm{CO}_{2}, \mathrm{SO}_{2}, \mathrm{NOx} \text { and energy } \\
\text { resources }\end{array}$ \\
\hline Less toxic building materials & Improved indoor climate, less toxic waste \\
\hline Recycling/building design & $\begin{array}{l}\text { Reduction of material consumption. Approx. } 20 \% \text { of building } \\
\text { materials end up as waste during the construction phase. }\end{array}$ \\
\hline More sustainable services & $\begin{array}{l}\text { Depending on service less waste, energy consumption or } \\
\text { use of chemicals may be achieved }\end{array}$ \\
\hline Flexible non-residential buildings & Less resource consumption and construction waste \\
\hline
\end{tabular}

In the following, some of the eco-innovative solutions are described.

\section{Energy control systems}

An increasing part of PP related to hiring and buying buildings is requiring energy control systems to be provided in a mix of hardware and software. Many advanced systems are available and there is substantial potential for more energy effective buildings within the public sector. The potential for the average Nordic office building for electricity savings is 15-20\% according to Enova ${ }^{22}$. The average energy consumption of energy after technical renovations is $250 \mathrm{kWh}$ per $\mathrm{m} 2 \mathrm{pr}$ year. New buildings that are optimally designed consume as little as around $110 \mathrm{kWh}$ per $\mathrm{m} 2$ pr year. ${ }^{23}$

\section{Low toxic materials}

Low- or non-toxic materials has benefits in several ways; Improved indoor climate, lower ventilation requirements, better health and less toxic waste. There is a lack of knowledge concerning chemicals in the construction business and considerable room for improvements.

\subsubsection{Barriers for exploiting the eco-innovation potential}

Many eco-innovative solutions exist. The main challenge is to establish mechanisms introducing the technologies to the market in a broader scale.

\footnotetext{
${ }^{22}$ Interview with Jan Peter Amundal, Enova, the Norwegian organization for change of energy use and energy production.

${ }^{23}$ YIT, Jens Petter Burud, energy expert
} 
The surveys have identified the following general barriers for development of eco-innovation through public procurement:

1. Contract culture. Most building projects are carried out as tenders with strict contract relations between the stakeholders with focus on time, cost and quality.

2. Errors (for example due to experiments with new solutions) may not show up before long after project delivery. As they may turn out to be very costly to alleviate or remove, there is a tendency to continue with well known quality.

3. The distribution of technological and financial risks and rewards does not cater for an innovative process. Long term financial rewards from, e.g., energy efficient buildings are allotted to end users, whereas risk of technological failure lies with the constructor(s).

4. The divided process of the building chain complicates cooperation on eco-innovative solutions. The design phase is typically separated from the construction phase, and building material suppliers are often not involved in the design or building process. Thus, lessons learned in one system area are often not passed on to another.

5. The organisation of each project is more or less unique with different companies entering into temporary cooperation for the specific project. A cooperation based on temporary contracts between changing groups of actors makes the learning process more difficult and slows down innovation.

6. Extensive number of stakeholders. If innovative solutions are to be implemented they have to be accepted and implemented by a long list of stakeholders: Building owner, consultant, architect, contractor and subcontractors. Experience shows that good innovative ideas can very easily be excluded by one of the above stakeholders during the process. It is not sufficient to make one or two stakeholders accept the implementation of a new idea, the whole value chain must be consulted and convinced.

7. Infrastructural demands may make it difficult to plan and achieve legal permissions to use other solutions than the existing infrastructure for water supply, sewage, waste, and energy supply.

8. Cross ownership or strong partnerships amongst large stakeholders is widespread, e.g. contractors which own shares in mineral insulation. The cross ownership causes difficulties for alternatives to reach the market.

9. Lack of life cycle cost thinking in the sector. There is no tradition for providing clients with information and scenarios of life cycle cost illustrating both investment cost and operating cost. Neither is there any request for this information from public procurers as a part of the tender process. 
10. Politicians, housing organisations and others need more practical knowledge and visible demonstration of the building sector's ability to provide competitive environmental quality buildings.

\subsubsection{Challenges}

The key challenge in this sector is to utilize and implement already existing eco-technologies and methods and make them "state-of-the-art" in the public sector. On top of this, new innovative solutions can be innovated. Key stakeholders in this process are the public building owners and public procurers of buildings.

Based on the eco-innovative potential, the following key features can be highlighted:

- Influence: Construction operates on a local market. Clients have high influence on development of construction work.

- Legislation: Legal framework, especially for local spatial planning and building regulative, determine limits for eco-innovative solutions for construction work

- Innovation strategy: Stakeholder-focus on construction cost which stimulates innovation of cost effective solutions for the construction phase. This focus contradicts in general with eco-innovative solutions there mainly provides technologies which course savings during use/operation of the buildings. Low cost products which fulfil both legislative requirements and provide eco qualities can be implemented instantly.

- Technology trend: Suppliers have an ongoing incremental development of eco-innovative technologies, equipment and materials. Example with development of radical eco-innovative solutions is limited, propably because of the very different request and terms from clients.

- Innovation platform: Project / object oriented culture and dialogue perfect as eco-innovation platform

- Resources: Lack of venture capital to develop eco-innovative buildings

\subsection{IT products and related service}

The following dominating IT products have been selected for ecoinnovation discussions:

- Hardware

- Office equipment (PCs, monitors, printers)

- Server systems

- Storage systems 
- Communications systems

- Data centres

- Software

- Software efficiency

- $\quad$ Software solutions

\subsubsection{Key characteristics}

The IT sector has the following characteristics relevant for this analysis:

- The sector is dominated by large suppliers with extensive control and bargaining power.

- Innovation is driven by technology push and not market demands.

- Competition between market players is extensive with focus on price in combination with (new) features.

- Environment is a well known issue and product development of computers has some focus on energy consumption and hazardous substances (EU market).

- The public Nordic market is not crucial for large suppliers of standard office equipment - but interesting as a trend spot market.

- Software products provide interesting environmental potential but there is a lack of environmental focus among product developers and procurement officers.

\subsubsection{Eco-innovative potentials}

The IT sector is generally regarded as one of the most innovative sectors worldwide. The sector has one of the highest percentages of turnover invested in R\&D and few products can be sold five years after production. During the last decade there has been a significant "green" development within the sector and the climate debate has put even greater emphasis on environmental effects. The global data storage doubles every 18 months, which require more equipment and energy consumption ${ }^{24}$.

Table 4.4 presents a number of relevant eco-innovative solutions identified during the Nordic surveys. The environmental effect of the solutions is mainly related to energy saving during the lifetime of the electronic goods, saving of resources in production, and reduction of waste from consumption.

\footnotetext{
${ }^{24}$ http://www.digi.no/php/art.php?id=515515
} 
Table 4.4 Potential eco-innovative solutions related to IT product and services

\begin{tabular}{|c|c|}
\hline Eco-innovative solutions & Innovative and environmental effect \\
\hline Low energy PCs & $\begin{array}{l}\text { Energy savings during operation, } 80 \% \text { or more, leading to } \\
\text { reduced emission of } \mathrm{CO}_{2}, \mathrm{SO}_{2}, \mathrm{NOx} \text { and less consumption } \\
\text { of energy resources }\end{array}$ \\
\hline Thin Clients & $\begin{array}{l}\text { Energy saving through smaller units and centralized data } \\
\text { in server systems. Reduction of } \mathrm{CO}_{2}, \mathrm{SO}_{2}, \mathrm{NOx} \text { and } \\
\text { energy resources }\end{array}$ \\
\hline $\begin{array}{l}\text { Expanded recycling - closed loop } \\
\text { material recycling }\end{array}$ & $\begin{array}{l}65 \% \text { recycling of incoming equipment is possible. One } \mathrm{kg} \\
\text { recycled material saves two } \mathrm{kg} \mathrm{CO} \text {. }\end{array}$ \\
\hline Improved packaging & Reduction of cardboard, foam and weight per unit. \\
\hline $\begin{array}{l}\text { Low energy server systems with } \\
\text { improved data storage and design of } \\
\text { data centres }\end{array}$ & $\begin{array}{l}\text { Energy saving. Reduction of } \mathrm{CO}_{2}, \mathrm{SO}_{2}, \mathrm{NOx} \text { and energy } \\
\text { resources. The global data storage doubles per } 18 \\
\text { months. Potentials in relation to design of cooling, utilizing } \\
\text { of heat and administration software }\end{array}$ \\
\hline $\begin{array}{l}\text { Low energy communication systems } \\
\text { (routers, hubs, phones, antennas etc) }\end{array}$ & $\begin{array}{l}\text { Energy saving. Reduction of } \mathrm{CO}_{2}, \mathrm{SO}_{2}, \mathrm{NOx} \text { and energy } \\
\text { resources. Large saving potentials through improved systems }\end{array}$ \\
\hline Energy efficient software & $\begin{array}{l}\text { Energy saving. Development of applications improving the } \\
\text { use of CPU }\end{array}$ \\
\hline Digital services & $\begin{array}{l}\text { Energy and resource saving (paper and transport). Devel- } \\
\text { opment of digital public services and electronic document } \\
\text { sharing. }\end{array}$ \\
\hline Virtual meetings & $\begin{array}{l}\text { Energy saving, reduction of transport. Development of } \\
\text { software and facilities for virtual meetings }\end{array}$ \\
\hline $\begin{array}{l}\text { Procurement of IT services instead of } \\
\text { IT products }\end{array}$ & $\begin{array}{l}\text { More flexibility in relation to hardware use and material } \\
\text { consumption }\end{array}$ \\
\hline
\end{tabular}

In the following, the potential solutions are described in more detail.

PCs

Energy consumption during stand-by is remarkably high for many types of equipment, even though energy consumption of PCs and equipment has been a key focus area for many years and considerable R\&D resources have been allocated to the topic.

Table 4.5 Typical energy consumption from standard PC equipment

\begin{tabular}{lrrrr}
\hline Unit* & On (Watt) & Sleep (Watt) & Stand-by (Watt) & $\begin{array}{r}\text { Total per year } \\
\text { (kWh/year) }\end{array}$ \\
\hline Standard Stationary PC & 150 & 14 & 8 & 218 \\
Energy saving stationary PC & 30 & 2,5 & 0,5 & 35 \\
Portable PC & 16 & 0.5 & 0.5 & 20 \\
\hline
\end{tabular}

* www.elsparefonden.dk.

** Time on: 1,032 h; Time sleep: 234 h; time stand-by: 7494 .

To stimulate eco-innovation environmental requirements would have to be continuously harsher than the existing standards as stipulated in the existing eco-labels. 


\section{Thin Clients}

Thin clients are small PCs where data power is centralized in a server system which the thin clients are linked to. The server runs all the software and the thin client acts as a terminal. This technology is developing fast and opens up for substantial decrease in electricity consumption. Thin clients are estimated to have a potential saving in the Norwegian market of up to $400 \mathrm{GWh}^{25}$.

\section{Reuse and recycling}

Further development of reuse and cycling concepts can be developed in which functional equipment is taken back and upgraded for resale. A Norwegian PC-return concept shows 65\% reuse of incoming equipment and extended life span for this IT equipment by $3-4$ years $^{26}$. Closing the material life cycle is another interesting challenge for IT eco-innovation. One $\mathrm{kg}$ of recycled material saves two $\mathrm{kg}$ of $\mathrm{CO}^{27}$.

\section{Reduction of packaging}

A few success stories show that it is possible to reduce packaging of IT by setting up requirements. Statoil demanded Dell to deliver PCs with less packaging and ended up with a system where one box contained ten PCs. Dell now offers this as an option to all customers.

\section{Server systems}

Server systems constitute a product group of less global and mass produced nature than PCs and related equipment, with a total volume comparable with personal computers - and with high profits. One international manufacturer informs that of their total production, PCs constitute $33 \%$, printers $25 \%$, and the rest is made up of servers systems (around $40 \%$ ). Approximately $20 \%$ of all server systems are procured by public organizations.

There is a substantial potential for reduced electricity consumption from server operation and cooling. In the UK alone it is estimated that 7 $\%$ of power is consumed by data centres - an increase from $4 \%$ in three years only ${ }^{28}$.

Many installations in Scandinavia today have Total Facility Power (PUE) $^{29}$ at 2.0. In 2008 a new server centre was installed in Sweden reaching a PUE value of 1.23 , and server installations can possibly reach PUE values below $1^{30}$. PUE below 1 can be reached when excess heat can be used elsewhere.

\footnotetext{
${ }^{25}$ http://www.digi.no/php/art.php?id=520254

${ }^{26}$ Hege Skodje, project coordinator, Alternativ Data, Norway

${ }^{27}$ Ruediger Kuehr, researcher, author of "Computers and the Environment"

${ }^{28}$ US Census Bureau, Symantec

${ }^{29}$ (PUE = Total Faciltiy Power / IT Equipment Power.) http://www.thegreengrid.org/gg_content/ TGG_Data_Center_Power_Efficiency_Metrics_PUE_and_DCiE.pdf

${ }^{30}$ www.metric.no
} 


\section{Server system concepts}

The market for public organization server systems can be divided into three main groups:

1. The organization hosts and operates it own servers, or

2. The organization's servers are installed at a large service provider (such as KMD or CSC in Denmark) that takes care of the daily operation, or

3. The organization has outsourced the whole server system operation to the service provider and does not own any server system itself.

Server systems are typically not procured by public procurement officers but by IT departments with assistance from external consultants.

There are extensive options for improvement of servers' electricity consumption, power supplies/UPS, cooling of server rooms, utilization of excess heat and software systems installed.

Seven to ten large manufacturers dominate the Nordic server market for public organisations and it appears feasible to influence these manufacturers with environmental requirements.

\section{Communication systems}

Communication systems is different hardware units such s specialized boxes, routers, switches, fire walls, phones, antennas and cables. Communication systems are some of the most neglected areas for ecoinnovative initiatives in public procurement, even though the energy saving potential is considerable and it represent a relatively large share of the total hardware's energy consumption. An estimate indicates that Norwegian public organizations may save up to 57 TWh per year by upgrading their communication systems with the most power effective switches on the market. ${ }^{31}$

\section{Data centre}

Areas of consideration in relation to design of data centres are:

- Type of cooling (air condition, fresh air cooling, water based cooling etc.)

- Utilization of excess heat

- Warm and cool areas

- AC or DC UPS's

- Administration software

\section{Energy efficient software}

An important but overseen issue in public procurement of IT is specifications related to core codes which can provide more energy efficient software running on the servers. Illustrating the potential savings there are

\footnotetext{
${ }^{31}$ Alcatel Lucent, Tore Evensen, Finansavisen (Norway), 2008-12-22
} 
examples of applications that have been written with codes demanding that the CPU is always running on $100 \%$ instead of being shut down when not in practical use.

\section{Digital services}

These services are not dependent on simultaneous software operation/usage. These must most likely be developed locally for each country. Examples are

1. Increased use of digital public services and digital invoices will reduce transportation and paper consumption/waste

2. Electronic document sharing / distribution via internet (web2 pages, email etc) will also reduce transportation and paper consumption/ waste.

A Norwegian initiative to digitalize the public information flow between local and central government and the individual/employing organizations (“Altinn”) have saved money, paper and transport of paper.

\section{Virtual meetings}

Virtual meeting can be held through the use of PCs or specialized video conferencing rooms, reducing the need for transportation. In addition to voice transfer such meetings may include video and document sharing. Many software solutions exist and public procurement may be a driver toward better systems and setups.

There are many areas where such systems can be used, but the public sector need strategies, equipment and concepts. The Norwegian insurance company Vesta saves NOK 18 million and reduces $\mathrm{CO}_{2}$ emissions by 525 tonnes per year by using video conferences ${ }^{32}$. Estimates show that if 20 $\%$ of German business travels were exchanged with video conferences the $\mathrm{CO}_{2}$ reduction would attain 5.2 million tonnes ${ }^{33}$.

\section{Procurement of IT Services instead of IT products}

For specific technologies the market today offers services as an alternative to traditional products (software/hardware), for example storage of documents according to specific criteria in an external server park.

\subsubsection{Barriers for exploiting eco-innovative potential}

1. Small Nordic market. It is difficult for the Nordic countries to influence innovation within internationally mass produced standard products such as PCs and copying machines due to the relatively small Nordic purchasing volume in a global perspective. The Nordic coun-

\footnotetext{
${ }^{32}$ http://arkiv.na24.no/NewsTag.asp?Tag=Bellona\&Pos=25

${ }^{33}$ http://arkiv.na24.no/Nyhet/231377/Tjener+på+klima-bråk.html
} 
tries are considered an advanced market that indicates future worldwide demand.

2. Public organization competences in procurement of IT. Rapid development of new solutions makes it difficult for purchasers to be updated, also on environmental issues. In many organisations the internal dialogue between procurers and IT departments is sparse. Dialogue within organization and also with suppliers is important because IGPP requires different types of expertise (technical, procurement, environmental etc.). Communication with suppliers/IT is necessary so that suppliers learn what organizations really need now and in the future, and so that procurers and IT departments gain an understanding of the market situation and new innovations. For example, In Sweden and Finland the centralized State procurement organizations engage the suppliers extensively, which has been a driver for innovations in the IT sector.

3. Non-holistic focus. Different requirements quite often conflict with each other. High demands on energy effectiveness may risk subordinating green demands on materials and resources, and fire protection rules have opened up for brominated flame retardants.

4. Too long procurement process. Procurement processes of advanced and complicated systems like servers and storage systems are often very long. From specification to implementation may take up to three years, because of complex needs assessments, criteria specification and approval process, which often involve many levels in the organisations. The risk is that equipment when finally installed is outdated, so far more environment-friendly and effective solutions could have been implemented.

5. Life cycle cost for electricity not transparent. One important barrier for improving electricity savings is the fact that the price of electricity consumption is typically not shown directly in the tender/procurement process. A study from Norway determined that only $15 \%$ of the analysed companies have transparent electricity cost related to the IT budget ${ }^{34}$. More focus on life cycle cost of the procured goods is needed in many procurement processes.

\subsubsection{Challenges}

A key challenge for public procurement of eco-innovative IT products and services is to build competences and know-how to request challenging demands and criteria in tenders. There is a need for competences in relation to technical specification, environmental benefits and life cycle cost.

Based on the eco-innovative potential, the following key features can be highlighted:

\footnotetext{
${ }^{34}$ http://www.steria.no/gloria/id/11004337/subid/0
} 
- Influence: it standard hardware operates at global market and influence is low. IT server system products operate at local market and influence on development of solutions is high.

- Legislation: The existing legislative framework stimulates ecoinnovation.

- Innovation strategy: Stakeholders focus on development of technological core features but environmental issues are integrated.

- Technology trend: Fast development of hardware core technoligies towards smaller mobile units with larger data capacity. Synergy between software and hardware development. No particular tradition for environmental focus in software development.

- Innovation platform: Concept oriented in relation to procurement of software and server systems.

IGPP can first of all be expected to have successful influence on the following stakeholders:

- Providers of server, storage and communication systems and

- Small suppliers of computers (assemblers)

- Local software developers

IGPP may have successful influence on:

- Large suppliers of hardware

IGPP cannot expect to have influence (besides regulation) on:

- Large core technology producers

- Large suppliers of basic materials

- Large suppliers of software programs

The Renewable Energies Unit of the Joint Research Centre in the EU released in October 2008 a Code of Conduct ${ }^{35}$ (CoC) on Data Centres Energy Efficiency. The Code of Conduct provides relevant information on standards and criteria useful in procurement of server systems.

\subsection{Taxi and bus services}

Public procurement of transport services is of considerable volume and includes taxi, buses, public transport, ambulance and fire service and transport of goods. The analysis has been delimited to taxi's and buses, constituting a considerable part of the public procurement of transport services and representing different types of vehicles.

\footnotetext{
${ }^{35} \mathrm{http} / / /$ re.jrc.ec.europa.eu/energyefficiency/pdf/CoC\%20data\%20centres\%20nov2008/CoC\%20 DC\%20v\%201.0\%20FINAL.pdf
} 


\subsubsection{Key characteristics and structure of the selected transport services}

Passenger transport services are normally procured for public service purposes such as public bus transport, school bus transport, transport of elderly, disabled or sick persons etc. This kind of transport services is provided under framework contracts and tenders. Another kind of transport procurement is when the individual public institutions use taxis for personal transportation for meetings etc. or for delivery services.

The main key characteristics in relation to eco-innovation are summarized below. As bus transport services and taxi transport are of a different nature, they are described separately.

\section{Taxi operation}

Taxi operation in the Nordic countries has the following key characteristics:

- The Nordic markets for taxi operation are organized with local or regional operators and the number of cars and operators is controlled through operation permits issued by public institutions

- Car/bus suppliers have extensive bargaining power and control with market development, and innovation is driven by the international regulation of standards for emission, safety etc. and trends for energy supply.

- The Nordic taxi market is strictly regulated with regard to maximum price and quality of the taxis. Price and standards differ between the countries.

- The public sector often makes framework tenders before contracting their needs. Especially within health related taxi operations.

- Although public institutions are large customers it is difficult to determine environmental requirements in tenders which exceed the general regulation.

- Taxi operators are private entities with focus on profit earned through operation and through resale of luxury cars to private market.

- Cars are continuously renewed and resold to private market by taxi owners. Taxi cars are typically between $0-2$ years old.

- Taxi cars are normally large luxury passenger cars manufactured by international car manufacturers

- Taxi cars are bought and owned by private taxi owners/operators and public organizations then buy taxi services from private taxi operators

- There are special tax regimes for taxi cars/operators which ensure affordable luxury cars for taxi operators because of tax reduced models.

- Taxis in the Nordic countries are required to fulfill standards in relation to safety and comfort

- Environmental issues are ensured through international emission regulation of vehicles

- Competition is controlled through operation permits and competition is generally low. 
- Taxi operators are interested in lower fuel consumption because reducing fuel consumption/costs is a means of cutting operating costs.

- The structure of the taxi market is generally divided into taxi owners and a central calling office. The taxi calling office must by legislation accept any taxi owner, who wants to be affiliated to the office, without making any claims or requirements.

Bus services

Bus services have the following key characteristics:

- Public bus transport in the Nordic countries is typically administrated by a local or regional transport company.

- Public procurement of bus services is mainly procurement of city bus transport which constitutes a major part of the market.

- The public sector can operate the buses themselves, but transport is mainly provided by private operators.

- Competition is normally strong and based on tender processes defining the financial framework of operation.

- All public transport is up to tender. Hence, public transport companies have good opportunities for including environmental issues in the tenders within the financial frame.

- Public tenders for bus transport, especially in city districts, determine emission criteria in different geographic zones and environmental criteria for maintenance.

- EU legislation defines environmental minimum emission requirements for buses bought in the EU.

- Old buses are normally not scrapped but sold to other countries where the need for comfort is lower than in the Nordic countries.

- The operator can receive payment per bus route - independent of the number of passengers travelling or a payment based on number of passengers.

- Bus vehicles are manufactured by national or international manufacturers.

- Buses are owned by both publicly and privately owned operators

- Bus operators are interested in lower fuel consumption because reducing fuel consumption/costs is a key means of cutting operating costs.

- Public organizations buy coach services from private/public bus operators.

- Rewarding schemes may be related to the quality of the service from the customer viewpoint: customer satisfaction, cleanliness of the vehicles, timeliness of service etc. They may help in gaining environmental benefits and increasing the attractivity of public transport. 
In general, taxi operation and bus services have many similarities among the Nordic countries with respect to market structure, value chain, and organisation.

\subsubsection{Product development among car and bus manufacturers}

Most vehicle manufacturers are large international companies who are affected most by the demand and legislation of the core markets: USA and the EU but also fast growing economies such as China and India.

Legislation is probably the single most important eco-innovation push factor for the car/bus manufacturing industry; the coming EU legislation will set even stricter limitations on vehicles' $\mathrm{CO}_{2}$ emissions (EURO norm) and will probably be one of the strongest eco-innovation drivers in the car industry over the coming years. Manufacturers are completely aware of the need to reduce fuel consumption and $\mathrm{CO}_{2}$ emissions because of increasing fuel prices, climate awareness and legislation.

Manufacturers focus on fuel consumption and emissions in their $\mathrm{R} \& \mathrm{D}$. Virtually all car manufacturers are developing more environmental cars such as hybrids, fuel cells etc. but development is time consuming and costly and relatively few alternative cars are still commercially available and economically feasible for most procurers.

All bus manufacturers have invested in development of alternative technologies such as hybrid technology, fuel cell technology and engines powered by alternative fuels. The development of hybrid technology and fuel cell technologies is extremely costly.

Mercedes-Benz Buses and Scania have been involved in testing of their vehicles, in cases where they have been sold on pre-commercial basis. Procurement of Scania's hybrid buses have not led to an increase in orders for buses (Urban Wastljung from Scania Buses, 5. June 2008).

Bus manufacturers agree that the best way to support development of more environment-friendly buses is to include performance requirements in tendering. The lead time of developing new technology is long in the industry, and manufacturers therefore stress the importance of formulating technical specifications for new buses long in advance. For buses to be procured in 2020, requirements should be set up now. If procurers adhere to these requirements, it will be possible for bus manufacturers to provide the technology (Urban Wastjlung, 5 June 2008; Michael Goepfart, 29 May 2008; Ulf Gustavsson, 16 May 2008).

Development of radical eco-innovations in the car industry is extremely costly and has a long lead time. Some large car manufacturers, such as Honda and Toyota, have developed hybrid technologies, and Honda has recently commercialised a fuel cell powered car. Similary SAAB has made incremental changes to their existing internal combustion engines that have made it possible to use $85 \%$ bio-ethanol fuel to power the vehicles. 
Car manufacturers will probably not see eco-innovative public procurement as a realistic tool to develop new vehicles as the development of new technology is very costly and the public sector's procurement of cars does not constitute a sufficiently large share of the market making it economically feasible to develop special environment-friendly cars. On the other hand, PP in Sweden has had been considered as a market turnkey in Sweden where incentives (such as defining eco cars in PP) have favoured alternative fuels. New eco-innovations have also been tested in the public sector, for example hybrid busses are being tested and used already in for example Stockholm and Helsinki.

\subsubsection{Eco-innovative potentials}

On the European Innovation Sector Scorecard of 2005, transport is doing well. Of the 25 product groups ranked "Motor vehicles, trailers and semi trailers" are ranked as number five, and general "Transport Equipment" is ranked as number seven, while "Transport, storage and communication", which includes Taxi operation, is ranked as number 24.

Table 4.6. presents a number of relevant eco-innovative potentials identified in the Nordic surveys. The environmental effect of the solutions varies but is mainly related to energy saving and emission reduction.

Table 4.6 Potential eco-innovative solutions related to taxi- and busservice

\begin{tabular}{|c|c|}
\hline Eco-innovative potentials & Innovative and environmental effect \\
\hline $\begin{array}{l}\text { Taxis with improved fuel } \\
\text { economy }\end{array}$ & $\begin{array}{l}\text { Energy saving and emission reduction. Development of new } \\
\text { incentives to increase use of eco-friendly cars }\end{array}$ \\
\hline Eco taxi & $\begin{array}{l}\text { Energy saving and emission reduction through improved organisa- } \\
\text { tion of logistics and maintenance. }\end{array}$ \\
\hline Eco driving & $\begin{array}{l}\text { Saving of } 5-10 \% \text { on energy consumption. Development in docu- } \\
\text { mentation and training models for eco driving. }\end{array}$ \\
\hline Taxis with alternative fuel & $\begin{array}{l}\text { Emission reduction. Development of economic incentives and } \\
\text { supply infrastructure }\end{array}$ \\
\hline Electric vehicles & $\begin{array}{l}\text { Emission reduction, more energy efficient use. Development of } \\
\text { technology and infrastructure }\end{array}$ \\
\hline Bicycle taxis & $\begin{array}{l}\text { Energy saving and emission reduction. Development of market } \\
\text { and concepts in city districts }\end{array}$ \\
\hline $\begin{array}{l}\text { Computer based information } \\
\text { technology (ICT) }\end{array}$ & $\begin{array}{l}\text { Energy saving. Development of improved logistics from taxi call } \\
\text { offices to taxis and available and transparent information, e.g. on } \\
\text { fuel consumption. }\end{array}$ \\
\hline $\begin{array}{l}\text { More passengers through } \\
\text { improved bus service }\end{array}$ & $\begin{array}{l}\text { More energy efficient transport. Development of new contract } \\
\text { models }\end{array}$ \\
\hline $\begin{array}{l}\text { Buses with alternative fuel or } \\
\text { electricity }\end{array}$ & $\begin{array}{l}\text { Emission reduction. Development of infrastructure and vehicle } \\
\text { technologies }\end{array}$ \\
\hline
\end{tabular}

In the following, more details on eco-innovation potentials are described in relation to the two selected product groups. 


\section{Taxi operation}

To think "green" within the taxi business is a relatively new area for taxi owners. Focus has primarily been on comfort, price and working environment. However, the ongoing focus on climate and increasing interest from costumers has generally made the business more aware about options and alternative services.

\section{Smaller cars with improved fuel economy}

Taxis in the Nordic are in general large fuel consuming cars and often there are only one or two persons in the taxi, so lighter and more fuel efficient taxis would normally be sufficient.

The challenge is to remove the barriers to get more fuel efficient cars introduced into the Nordic taxi market. At present, legislation is a barrier and will need to be changed. Furthermore, taxi owners have no economic incentive to use smaller cars e.g. in terms of lower tax. A tax model providing lower tax and free parking for eco-friendly cars using biofuel, has been applied in, a.o., Stockholm where green taxis today constitute a large number of the total number of city taxis.

Environmental effects from introducing more fuel efficient cars are relatively low. To get a relative indication of the environmental potential in terms of $\mathrm{CO}_{2}$ reduction, the following calculation has been made: $\mathrm{A}$ Mercedes-Benz C 200 CDI aut. emits $171 \mathrm{~g} \mathrm{CO}_{2} / \mathrm{km}$ while a Toy-

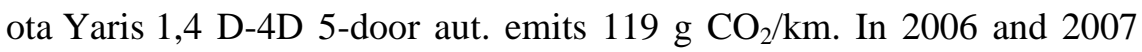
the Danish taxi transport amounted to 408 million person-km (www.statestikbanken.dk). If $25 \%$ of the transport were provided by smaller cars the reduction would be 5,200 tonnes of $\mathrm{CO}_{2}$.

\section{Ecotaxi}

In Finland the Taxi Owners' Association has an environmental programme "ekotaksi" (ecotaxi), which may act as a catalyst for ecoinnovation in the country's taxi sector. Ecotaxis are taxis that partake and commit to the ecotaxi programme. Ecotaxis may use the ecotaxi logo in their car, which helps customers recognising them. The programme pays attention to environmental aspects in the selection/purchasing, use and maintenance of the vehicle. The number of these ecotaxis is growing but still limited. The ekotaksi status can be used as a means of verification if an environmental management system/programme is required from the operator. Normally, the taxi call centres send the closest available taxi to the customer, which minimizes unnecessary driving and is a good environmental practice as such.

It is also possible to order an "ecotaxi” specifically, but this is possible only if there are available ecotaxis and environmentally feasible only if there is an available ecotaxi close to the customer. If the ecotaxi has to drive a long distance to reach the customer, the environmental benefits will be lost. However, the situation may be different with taxi calls that 
are regular or scheduled well beforehand (i.e. transportation of school children or elderly/disabled). Scheduled or pre-ordered taxi calls are an area where public procurers could apply ecocars effectively. The Finnish experience so far is that in overall, there is a lack of both demand and supply.

\section{Eco driving}

Taxi service operator can save 5-10 \% of fuel per kilometer through eco driving. Training in eco driving can be documented through certificates. From an eco-innovative public procurement point of view it is a so-called "low hanging fruit" exercise, as innovation is mainly organizational and requires only development of systems for documentation and tender framework.

In Finland the development of a system of energy audits for the transport chain will help the purchasing entities to identify improvements from an environmental and efficiency point of view. This information can then be used as a basis when purchasing transport services.

\section{Alternative fuel}

Bio-fuel, biogas and electricity are the key alternative fuel sources at the moment. The environmental effect is quite substantial. In Stockholm, 20$25 \%$ of taxis are using bio-ethanol. There has been interest in cars running on bio/natural gas among taxi owners, but currently infrastructure for distributing gas is insufficient. This is a problem especially for taxis that drive irregular routes.

The CO2 emission from cars using biogas are 8-15 g CO2 pr. km and $60 \mathrm{~g}$ pr. $\mathrm{km}$ if the fuel are 50/50 mix of natural gas and biogas. Compared to diesel and gasoline, the $\mathrm{CO} 2$ emission reduction is substantial. For pure biogas it is up to $1 / 10$.

Biogas are used in means of transport in following countries; Sweden, Germany, France, United Kingdom. ${ }^{36}$

\section{Database on fuel consumption and emissions}

Databases (e.g. EkoAke) help in market research and in identifying the best available technology on the market. It provides information on fuel consumption and emissions of all new cars sold. In Finland this service is produced by the Finnish Vehicle Administration (AKE) in cooperation with car manufacturers. The tool is public and available for private consumer as well as professional procurers. Public procurers or taxi owners can use the database to do market research and find the best available technology on the market. The database is quite new and perhaps not known among all procurers. A more effective use of the database might help to shift the demand and supply and eventually encourage ecoinnovations among suppliers.

\footnotetext{
${ }^{36}$ From article in Klima, Børsen 15. june 2009
} 


\section{Electric vehicles}

There are not yet commercially available electric vehicles that can be used as taxi cars. Electric vehicles can be charged from the grid/socket for instance in the garage and plans are made for selling changeable batteries for electric vehicles at gas stations in some of the Nordic countries.

Bicycle taxis

Bicycle taxis is a concept which is only an option for short distances. This service concept is provided e.g. in central Copenhagen, but is relatively new.

\section{ICT technology}

ICT is computer based information technology. Opportunities include:

- GPS systems in taxis help find the shortest and fastest route and help save energy

- car computers can give useful information and feedback on for instance fuel consumption

- taxi call centres appoint the customer to the closest available taxi, which is good environmental practice

\section{Bus services}

\section{More passengers}

A Swedish example from Helsingborg has shown that the contract structure is crucial and an area where GPP can make a difference in the form of payment structure. In Helsingborg operators get a bonus for more passengers under the contract. It has resulted in $18 \%$ more passengers using the buses, through better service and campaigns. The example shows that the way tendering and contracting between the public transport company and the private operators is made can influence the number of passengers.

\section{Alternative fuels}

For buses, several alternatives to diesel are available - hybrid, electricity, natural gas, biogas, and ethanol. For example, in Sweden buses in Stockholm are using ethanol to a great extent and some biogas as well. Approximately $25 \%$ of the city buses in Stockholm are now using renewable energy. In 2006, the reduction was 41,000 tonnes of $\mathrm{CO}_{2}$ reached by using 380 ethanol and 51 biogas buses. Hence, the environmental impact is undoubtedly substantial.

The use of alternative fuel in bus services is relatively straightforward as it may be a requirement in the tender documents. However, the cost might be substantial in the short term because an alternative fuel infrastructure must be developed and and new vehicles procured. Therefore, political will is a precondition for introducing such issues. 
To exploit the innovative potential it is very important to use open tenders as opposed to tenders with strict functional requirements. Tender documents should use phrases such as " $x$ percentage must be renewable fuel" instead of "x percentage must be bio gas" .

A shift to alternative fuels will in general require public investment in infrastructure and changes in the national tax systems. In Sweden there are examples of cooperation between biogas producers and bus operators in public transport, where some of the cities" local buses run on local biogas. In Sweden this is economic interesting for bus operators, while biogas have no taxes which mean the fuel price for biogas is $20 \%$ cheaper than diesel. In Denmark for instance, there are taxes on biogas, which mean that biogas are $10 \%$ more expensive than compares to diesel.

\section{Electric trolleys}

Electric trolley buses are available in Europe although they are not used widely in the Nordic countries.

\subsubsection{Barriers for exploiting eco-innovation potential}

The surveys have identified the following general barriers for development of eco-innovation of taxi operations and bus services through green public procurement:

1. Lack of supporting infrastructure to support alternative solutions such as bio-fuel and electric vehicles and more use of ICT technologies. Contractors need to be encouraged through political visions and implementation of appropriate infrastructure.

2. Lack of financial and legal incentives which motivate taxi operators to buy and use low energy consuming cars or cars with alternative fuels. There are often no significant financial incentives that would encourage choosing eco-vehicles or transport services in the Nordic countries (except Sweden).

3. Lack of exchange of knowledge and experience regarding alternatives in procurement. Many procurers are interested in buying greener transport but often they do not have the time to follow up on state-ofthe-art in development and alternatives. Databases and other central knowledge sources can support them.

4. Small budgets for bus service. The public sector is more or less in a monopolistic situation within bus services. It is well known that environmental effects are substantial when improving the environmental performance of buses, but budgets still remain small. This makes it difficult to negotiate eco-innovative vehicles or performance in the tender process.

5. Need for more recommendations. Guidelines etc. for innovative green $\mathrm{PP}$ concerning procurement of taxi operations and bus services affect 
positively public procurers: for instance The Ministry of Transport and the Association of Finnish Municipalities in Finland have guidelines for the procurement of transportation services and in Sweden there is a PP guideline on eco-vehicles.

6. Improved transparency between investment cost and life cycle cost (LCC). Improving environmental/energy performance may require investments but they may be worthwhile when considering pay-back times and life cycle costs (LCC). Procurers need more data on life cycle cost and pay-back times of new technologies.

7. Risk bearing and quality demands. New products hold both an improvement potential as well as a risk to the buyer in case they do not perform as intended. Additionally the investment cost may initially be higher compared to a "normal" product. Procurers need more information on how to manage risks with for instance contract conditions etc. Financial instruments for risk bearing are needed. It may be very challenging for both producers and procurers to try out new innovations if the quality requirements are very high.

8. Resale to private market. Taxi operators are private companies which earn profits through resale of luxury cars to private market. It makes it more difficult to introduce other car models which are smaller and more environment-friendly, while the yield from resale to private market will decrease.

9. Taxi call centres obliged to treat the members equally. A costumer cannot order a "green" taxi as this would result in the affiliated taxis not having equal opportunities for a ride. Due to this structure of the local taxi market it is difficult for public procurers to include environmental requirements in tenders. The taxi call centres ${ }^{37}$ must accept any taxi owner wishing to be affiliated to the call centre, without making any claims or requirements. Since the call centres are the bidders on tenders they cannot relate to environmental requirements because they have no influence over affiliated members.

\subsubsection{Challenges}

The key challenge in this sector is to utilize and implement already existing eco-technologies and methods and make them "state-of-the-art" in the public procurement.

Based on the eco-innovative potential, the following key features can be highlighted:

- Influence: The selected transport services operate on a local market. Clients have high influence on demands with respect to emissions, fuel consumption, eco driving requirements, ICT etc.

${ }^{37}$ A "Central calling office” is an affiliation of taxis owners acting as one taxi company. These companies call the tenders made by the public. 
- Legislation: The legislative tax framework for taxi operation constitutes an incentive to keep using luxury cars, which can be resold to private market.

- Innovation strategy: Operators focus a.o on reducing operating cost and improving service which stimulate technologies reducing fuel consumption cost or maintenance cost if investments do not increase. Operators innovation strategy can only be related to concept development while vehicle manufactors innovation cannot be influed by demands from operators.

- Technology trend: Ongoing development of eco-innovative technologies for vehicles (emission and fuel consumption).

- Innovation platform: Mainly located at manufactors of vehicles and supporting technologies. 


\section{Socio economic assessments}

\subsection{Approach}

A pragmatic and rather simple approach has been chosen to discuss and illustrate the socio economic implications from improvement of eco-innovation in the three selected product groups (IT, Construction, Transport).

Three specific case calculations are carried out. The case calculations include a quantitative cost-benefit analysis (CBA) of replacing a "standard" or conventional product by an eco-innovative or environmentally friendly product.

The quantitative analysis, however, only covers the direct effects of the public procurement and externalities related to energy production (power and heat). Therefore, the cost-benefit analyses are supplemented by discussions of the non-quantified effects. These include direct and indirect effects such as environmental effects which should ideally be included in the cost-benefit analysis, but also "wider economic effects" such as effects on employment.

\section{Limitations of CBA}

The cost-benefit analysis rests on a number of crucial assumptions, including the assumption of "known technology". In other words, it is a basic assumption that technologies and their costs are well known. With regard to the development of eco-innovative products, this condition is often not fulfilled because the products in question are not yet fully developed or fully matured. This implies that the costs as well as the specific product features are not known at the time of carrying out the analysis. Therefore, there are limitations of applying the CBA approach in relation to assessing the economic implications of eco-innovative products.

The CBA constitutes a good starting point for analysing the economic implications of eco-innovative products as the method provides for a systematic and theoretically well-founded approach. However, there are certain limitations to the merits of the CBA in general and in relation to eco-innovative products. For example the CBA does not include wider economic effects on costs, competition, employment and export - sometimes also called dynamic and strategic effects.

There is a "learning curve effect" when new eco-innovative products are developed. This means that there is an economic benefit from "learning” which increases productivity and efficiency over time producing a product. Hence, public procurement not only potentially supports the development of new products and services but it can also develop the manufacturing expertise needed to produce the technology efficiently. 
Learning curve advantages include benefits in terms of lower production costs but also benefits in terms of pushing innovation to the next level.

\subsection{Case calculations}

Economic impacts of the cases below are analysed in a standard CBA framework supplemented by a short discussion of its limitations in the light of the discussions above.

Three specific cases of replacing a conventional product by an ecoinnovative or environmentally friendly product are presented. The case descriptions include a quantitative economic assessment - a CBA - in which the direct effects and the externalities from energy production are quantified. In addition to the case calculations, there is a short discussion of the non-quantified effects and of possible wider economic effects not included in the partial cost-benefit analysis.

The cases serve an illustrative purpose, and their assumptions are based on a relatively general set of data and information. The case study cost-benefit calculations and results should be interpreted with care and should not be used to derive any conclusions with regard to the perspectives and opportunities of the specific products. At least not without also considering the non-quantified effects and possible wider economic effects not included in the partial cost-benefit analysis.

The specific economic assessment has been carried out for the following three cases (following an initial screening and selection):

- Data centres: Server rooms upgraded with regard to the newest environmental technologies with regard to servers, software and cooling.

- Construction of buildings: Construction of low-energy consuming buildings instead of standard buildings.

- Taxi transport with electric taxis replacing diesel taxis.

The results are presented in EUR/unit. All costs and benefits are annualised. The unit results are scaled up to the Nordic region using data on the number of units affected.

The economic assessment has been carried out according to Danish guidelines on CBA and with the official unit values for Denmark.

\subsubsection{Assumptions}

Specific data on costs and energy efficiency etc. used in the cases derive from the project's data collection. In addition to these data, some general data and assumptions have been applied (see table below). 
Table 5.1 Overall assumptions and key data sources

\begin{tabular}{|c|c|c|}
\hline & Value & Source / Description \\
\hline Discount factor & $6 \%$ & Ministry of Finance, 1999 \\
\hline Net duty factor & $17 \%$ & Ministry of Finance, 1999 \\
\hline Tax distortion factor & $20 \%$ & Ministry of Finance, 1999 \\
\hline Power and heat prices & & Danish Energy Agency, 2008 - table 6. \\
\hline Emissions factors, stationary sources & & Danish Energy Agency, 2008 - table 8. \\
\hline Emissions factors, mobile sources & & $\begin{array}{l}\text { External Costs of Transport, Euro } 4, \mathrm{CO}_{2} \text {-model } \\
\text { from Ministry of Transrport }\end{array}$ \\
\hline Valuation of emission, stationary sources & & $\begin{array}{l}\text { Danmarks Miljøundersøgelser. 2007. Projection } \\
\text { of Greenhouse Gas Emissions - } 2005 \text { to } 2030\end{array}$ \\
\hline Valuation of emission, mobile sources & & Transport economic figures vers 1.0 feb 08.xls \\
\hline
\end{tabular}

\subsubsection{Case 1 - Data centres}

The design of data centres plays an important role in relation to energy savings. With the latest solutions it is possible to significantly reduce energy consumption by choosing innovative types of cooling, utilising excess heat etc. Thus, this case illustrates a situation in which a server room is upgraded with the newest environmental technologies within servers, software and cooling. The result is a server system that takes up much less room and at the same time is much more energy efficient.

It should be mentioned that it is a very complex task to find a simple parameter that describes the energy efficiency of a data centre in a good way. The parameter used here is $\mathrm{kWh} / \mathrm{m}^{2}$ which is the parameter suggested by the company that provided the data. The parameter cannot necessarily be directly compared with other data centres since its value is very dependent on type and function of the specific data centre. What is relevant in this context is to determine the relative difference between a standard data centre and a future eco-innovative data centre.

The baseline scenario is represented by a server room where nothing new or extra with regard to environment-friendly adaptations has been done. The project scenario is represented by a server room fulfilling a similar purpose but where innovative and environment-friendly technologies are applied in terms of cooling, utilising excess heat etc. 
Table 5.2 Costs and energy consumption of a standard data centre and an environmentally friendly data centre

\begin{tabular}{|c|c|c|}
\hline & $\begin{array}{l}\text { Standard data centre (base- } \\
\text { line) }\end{array}$ & Environment-friendly data centre \\
\hline Specific definition of types & Data centre $-65 \mathrm{~m}^{2}$ & Data centre $-48,75 \mathrm{~m}^{2}$ (reduced by $25 \%$ ) \\
\hline Additional investment cost* & & $2,200,000$ SEK \\
\hline $\begin{array}{l}\text { Lifetime of investment - equip- } \\
\text { ment }(50 \%)\end{array}$ & $\begin{array}{l}5 \text { years (old system must } \\
\text { be upgraded) }\end{array}$ & 5 years \\
\hline $\begin{array}{l}\text { Lifetime of the investment - room } \\
\text { design (50\%) }\end{array}$ & $\begin{array}{l}20 \text { years (room must be } \\
\text { renovated) }\end{array}$ & 20 years \\
\hline $\begin{array}{l}\text { Operation and maintenance costs } \\
\text { for each type, excl. Energy }\end{array}$ & $1,500,000$ SEK/year & $1,500,000 \mathrm{SEK} /$ year \\
\hline Energy consumption for each type & $\begin{array}{l}\text { Average consumption } \\
\text { of } 2.46 \mathrm{kWh} / \mathrm{m}^{2} \text { per hour }\end{array}$ & $\begin{array}{l}\text { Average consumption of } 1.73 \mathrm{kWh} / \mathrm{m}^{2} \\
\text { per hour }\end{array}$ \\
\hline $\begin{array}{l}\text { Number of units for the countries } \\
\text { involved }\end{array}$ & 4,000 centres & 4,000 centres \\
\hline
\end{tabular}

Source: based on Coromatic, Sweden and MakeITgreen/Erich Must Wessel, Norway

* Only additional costs for environment-friendly data centre compared to standard centre

The table above presents data for the standard data room with standard equipment and an environmentally friendly room with energy efficient equipment. The two scenarios differ in investment costs and energy consumption.

Based on the case specific assumptions above and the overall assumptions and key general data, cost-benefit calculations for the two scenarios have been carried out. The total net present value (NPV) of all costs per room has been calculated - financial costs (investments, O\&M and energy) and externalities (air pollution from power and heat production) - over the lifetime of the data centre (20 years). Then NPV has been annualised to express results in EUR/room per year. The table below presents the results.

Table 5.3 Total annual cost of standard and environment-friendly data centre

\begin{tabular}{|c|c|c|c|}
\hline EUR/room per year & $\begin{array}{r}\text { Standard data } \\
\text { centre }\end{array}$ & $\begin{array}{r}\text { Env. Friendly data } \\
\text { centre }\end{array}$ & Difference \\
\hline \multicolumn{4}{|l|}{ Financial effects } \\
\hline Investment cost & 0 & 31,708 & 31,708 \\
\hline O\&M (ex. energy) & 204,026 & 204,026 & 0 \\
\hline Energy costs & 102,881 & 54,264 & $-48,618$ \\
\hline Sum of financial effects & 306,907 & 289,998 & $-16,909$ \\
\hline \multicolumn{4}{|l|}{ External effects } \\
\hline Air emissions & 13,017 & 6,866 & $-6,152$ \\
\hline \multicolumn{4}{|l|}{ Other effects } \\
\hline Net duty & 52,174 & 49,300 & $-2,875$ \\
\hline Tax distortion & 71,816 & 67,860 & $-3,957$ \\
\hline Sum of economic effects & 443,915 & 414,023 & $-29,892$ \\
\hline \multicolumn{4}{|l|}{ Effect on $\mathrm{CO}_{2}$ emissions } \\
\hline $\mathrm{CO}_{2}$ emissions (tonnes/room per year) & 872 & 460 & -412 \\
\hline
\end{tabular}

Note: Own calculations. The results have been calculated using Danish emission factors and unit values. As a consequence results are only directly representative for Denmark. Especially $\mathrm{CO}_{2}$ emissions will differ between the Nordic countries due to large differences in energy production and associated average $\mathrm{CO}_{2}$ emission factors. 
The table shows that the total social cost of the environment-friendly data room is app. EUR 30,000 per year lower than that of the standard data centre. This is due to lower energy costs and reduced externalities which outweigh the higher investment costs (construction costs and data equipment).

The unit result can now be used to estimate total savings, if it is assumed that 4,000 data centres are rebuilt into environment-friendly data centres.

Total saving amount to EUR 120 million per year. Naturally, the full effect will only occur once all data centres have been rebuilt (after end of life of equipment and centres).

\subsubsection{Case 2 - Buildings}

Construction of new buildings has extensive potential for eco-innovation. This mainly relates to energy saving. Therefore, this case deals with construction of low-energy consuming buildings (project scenario) instead of standard buildings (baseline scenario). The table below provides an overview of the applied assumptions.

Table 5.4 Cost and energy consumption of standard and energy efficient buildings

\begin{tabular}{|c|c|c|}
\hline & Standard buildings (baseline) & Energy efficient buildings \\
\hline Specific definition of types & Avg. office building $-6,912 \mathrm{~m}^{2}$ & $\begin{array}{l}\text { Office building, wood and } \\
\text { concrete }-6,912 \mathrm{~m}^{2}, 2002^{(1)}\end{array}$ \\
\hline Investment cost & $10,000 \mathrm{DKK} / \mathrm{m}^{2(1)}$ & $10,422 \mathrm{DKK} / \mathrm{m}^{2(1)}$ \\
\hline Lifetime of investment & 25 years & 25 years \\
\hline $\begin{array}{l}\text { Operation and maintenance } \\
\text { costs for each type, excl. } \\
\text { Energy }\end{array}$ & $\begin{array}{l}\text { Maintenance: } 85 \mathrm{DKK} / \mathrm{m}^{2} / \text { year } \\
\text { Operation: } 250 \mathrm{DKK} / \mathrm{m}^{2}{ }^{(2)}\end{array}$ & $\begin{array}{l}\text { Maintenance: } 85 \mathrm{DKK} / \mathrm{m}^{2} / \text { year } \\
\text { Operation: } 250 \mathrm{DKK} / \mathrm{m}^{2} \text { (2) }\end{array}$ \\
\hline $\begin{array}{l}\text { Energy consumption for each } \\
\text { type }\end{array}$ & $\begin{array}{l}\text { District heat: } 75 \mathrm{kWh} / \mathrm{m}^{2} / \text { year } \\
\text { Power: } 44 \mathrm{kWh} / \mathrm{m}^{2} / \text { year }\end{array}$ & $\begin{array}{l}\text { District heat: } 12 \mathrm{kWh} / \mathrm{m}^{2} / \mathrm{year} \\
\text { Power: } 26,4 \mathrm{kWh} / \mathrm{m}^{2} / \text { year }^{(3)}\end{array}$ \\
\hline $\begin{array}{l}\text { Number of units for the coun- } \\
\text { tries involved }\end{array}$ & 15 mill $\mathrm{m}^{2(4)}$ & 15 mill m ${ }^{2(4)}$ \\
\hline
\end{tabular}

1) Source: Lavenergibygninger klasse 1, Det økologiske råd, 2. udgave 2007

2) Source: Average costs for public buildings from"Ejendomsadministration i kommuner

og regioner - Bedre rammer for velfærd", Danske Regioner, Erhvervs- og Byggestyrelsen, Finansministeriet, KL, Slots- og Ejendomsstyrelsen, Velfærdsministeriet. Maj 2008.

3) "By og Byg Dokumentation 006, Energibesparelser i nybyggeriet, Status år 2000" - power consumption of 44 kWh/ $\mathrm{m}^{2} /$ year. ERHVERVSAKADEMIET FOR BYGGE OG ANLFE assesses that energy efficient buildings can reduce power consumption by $30-48 \%$. Here it is assumed that power is reduced by $40 \%$.

4) This is equal to half of the public building mass - according to (2)

Data for an energy efficient building are based on an actual office building from 2002 located in Ulm, Germany, while the standard building is an office of the same size where standard data have been used. The investment cost for the energy efficient building is the actual cost, while the cost for the standard building is estimated based on references. Reference values of the investment cost various from being $0-12 \%$ higher for energy efficient buildings. Here approx. $4 \%$ is used; this illustrates that energy efficient buildings are a little more expensive to build due to better material but in 
the longer run, when eco-innovation has evolved, the difference will be considerably less than $12 \%$. Maintenance includes both indoor and outdoor maintenance while operation includes: taxes, insurances, administration, cleaning and caretaking (indoors and outdoors).

The table above presents data for two buildings fulfilling the same purpose (office building) - a standard building and an energy efficient building - and represents two different scenarios. Basically, the two scenarios differ in costs and energy efficiency as it is assumed that energy efficient buildings involve higher constructions costs, while the consumption of heat and power is reduced.

Based on the case specific assumptions above and the overall assumptions and key general data, cost-benefit calculations for the two scenarios have been carried out. Total net present value of all costs per $\mathrm{m}^{2}$ - financial costs (investments, O\&M and energy) and externalities (air pollution from power and heat production) - over the lifetime of the building has been calculated. Then NPV has been annualised to express results in $\mathrm{EUR} / \mathrm{m}^{2}$ per year. The table below presents the results.

Table 5.5 Total annual cost of standard and energy efficient building

\begin{tabular}{|c|c|c|c|}
\hline EUR $/ \mathrm{m}^{2}$ per year & Standard Buildings & Energy eff. Buildings & Difference \\
\hline \multicolumn{4}{|l|}{ Financial effects } \\
\hline Investment cost & 106.4 & 110.9 & 4.5 \\
\hline O\&M (ex. energy) & 45.6 & 45.6 & 0.0 \\
\hline Energy costs & 5.6 & 2.3 & -3.3 \\
\hline Sum of financial effects & 157.6 & 158.8 & 1.2 \\
\hline \multicolumn{4}{|l|}{ External effects } \\
\hline Air emissions & 1.0 & 0.3 & -0.6 \\
\hline \multicolumn{4}{|l|}{ Other effects } \\
\hline Net duty & 26.8 & 27.0 & 0.2 \\
\hline Tax distortion & 36.9 & 37.2 & 0.3 \\
\hline Sum of economic effects & 222.2 & 223.2 & 1.0 \\
\hline \multicolumn{4}{|l|}{ Effect on $\mathrm{CO}_{2}$ emissions } \\
\hline $\mathrm{CO}_{2}$ emissions ( $\mathrm{kg} / \mathrm{km}$ per year) & 34.8 & 18.2 & -16.6 \\
\hline
\end{tabular}

Note: Own calculations based on Table 5.. The results have been calculated using Danish emission factors and unit values. As a consequence results are only directly representative for Denmark. Especially $\mathrm{CO}_{2}$ emissions will differ between the Nordic countries due to large differences in energy production and associated average $\mathrm{CO}_{2}$ emission factors.

The table shows that the energy efficient building has the highest total social cost per year. Lower energy costs and reduced externalities are not sufficient to outweigh higher construction costs. Total social costs of the energy efficient building are app. EUR $1 / \mathrm{m}^{2}$ per year higher than the standard building.

The costs of $\mathrm{CO}_{2}$ are explicitly included in the analysis as the cost is internalised in energy costs. It is worth noting that the energy efficient building has approximately half the $\mathrm{CO}_{2}$ emissions of the standard building.

The unit result can now be used to estimate total additional yearly costs if it is assumed that around half of the public building mass in time will be built as energy efficient buildings. 
It is estimated that half of the building mass in the Nordic countries amounts to around 15 million $\mathrm{m}^{2}$. For these buildings, the additional annual costs amount to EUR 15 million per year. Naturally, the full effect will only occur once all public buildings have been rebuilt (after end of life of the buildings).

A sensitivity analysis has been carried out to establish how much higher the investment cost can be in an energy efficient building for the social cost-benefit calculation to break even considering the reduced energy costs. The analysis shows that the extra investment cost must be less than $3.5 \%$ larger to be socially beneficial.

\subsubsection{Case 3 - Taxi transport}

In the last case, it is assumed that a standard diesel taxi is replaced by an electric taxi. Electric vehicles are available on the market today, but they are still under development and they have not entered the vehicle mass market. Today, electric cars are more expensive than diesel cars but consume less energy. The potential of electric vehicles is high as they can reduce $\mathrm{CO}_{2}$ significantly, especially as more renewable energy is introduced in the power production system.

The table below provides an overview of the applied assumptions.

Table 5.6 Cost and energy consumption of standard diesel taxi and electric car

\begin{tabular}{|c|c|c|}
\hline & Diesel taxi (baseline) & Electric taxi \\
\hline Specific definition of types & Volvo V70 & Unspecified \\
\hline Price (ex taxes) & $220,000 \mathrm{DKK}^{(1)}$ & $400,000 \mathrm{DKK}^{(2)}$ \\
\hline Lifetime of investment & 10 years & $\begin{array}{l}10 \text { years (the battery accounts for app. } \\
40 \% \text { of the investment cost and has } \\
\text { an assumed lifetime of just } 5 \text { years }{ }^{(2)} \text { ) }\end{array}$ \\
\hline $\begin{array}{l}\text { Operation and maintenance } \\
\text { costs for each type, excl. } \\
\text { Energy }\end{array}$ & $\begin{array}{l}\text { Operation cost: } 94.5 \\
\mathrm{DKK} / 100 \mathrm{~km}^{(3)}\end{array}$ & Operation cost: 26.25 DKK/100 km ${ }^{(3)}$ \\
\hline Energy consumption & $14 \mathrm{~km} / \mathrm{l}^{(4)}$ & $0.180 \mathrm{kWh} / \mathrm{km}^{(5)}$ \\
\hline Traffic volume & 100,000 km/year & 100,000 km/year \\
\hline $\begin{array}{l}\text { Number of units for the } \\
\text { countries involved }\end{array}$ & $2100^{(6)}$ & $2100^{(6)}$ \\
\hline
\end{tabular}

1) Source.: “Trafikafgifter og klimapåvirkning, Hvordan sænker vi bilernes $\mathrm{CO}_{2}$-udledning?", Nor den 2008, Average price of app. 220,000 DKK for the five Nordic countries ex taxes

2) Source: Own estimate based on data from "Teknologivurdering af alternative drivmidler til transportsektoren". Electric vehicle app. 2.5 times more expensive than a diesel car.

3) Source.: http://www.folkecentre.net/dk/rd/transport/elbiler/elbiler_dk/

4) Source.: "Strategiplan for miljøsatsing" i Norges Taxiforbund

2) Source: Own estimate based on data from "Teknologivurdering af alternative drivmidler til transportsektoren". Medium diesel car $19 \mathrm{~km} / \mathrm{l}$, medium electric car consumes $0.133 \mathrm{kWh} / \mathrm{km}$. This relation is used to estimate consumption of electric vehicle

6) Equals the number of taxis in Copenhagen today

The table above presents data for two cars and represents two different scenarios that differ in costs and energy efficiency. 
Based on the case specific assumptions above and the overall assumptions and key general data, cost-benefit calculations for the two scenarios can been carried out. Total net present value of all costs per km over the lifetime of the cars has been calculated. Then NPV has been annualised to express results in EUR/km. The table below presents the results.

Table 5.7 Total annual cost of diesel and electric car

\begin{tabular}{lrrr}
\hline EUR/100km & Standard diesel car & Electric car & Difference \\
\hline Financial effects & & & \\
Investment cost & 4.1 & 18.3 & 14.2 \\
O\&M (ex. energy) & 12.9 & 3.6 & -9.3 \\
Energy costs & 3.3 & 1.3 & -2.0 \\
Sum of financial effects & 20.2 & 23.1 & 2.9 \\
& & & -0.9 \\
External effects & 1.1 & 0.2 & \\
Air emissions & & & 0.5 \\
Other effects & 3.4 & 3.9 & 0.7 \\
Net duty & 4.7 & 5.4 & 3.2 \\
Tax distortion & 29.4 & 32.7 & \\
Sum of economic effects & & & $-0,065$ \\
Effect on $\mathrm{CO}_{2}$ emissions & 0,190 & 0,125 & \\
$\mathrm{CO}_{2}$ emissions (kg/km per year) & & & \\
\hline
\end{tabular}

Note: Own calculations based on Table 5.. The results have been calculated using Danish emission factors and unit values. As a consequence results are only directly representative for Denmark. Especially $\mathrm{CO}_{2}$ emissions will differ between the Nordic countries due to large differences in energy production and associated average $\mathrm{CO}_{2}$ emission factors.

The electric car has the highest total social cost per $\mathrm{km}$. The lower O\&M and energy costs and reduced externalities are not sufficient to outweigh the higher cost for the car (and the battery). The total social cost of the electric car is app. EUR $3.2 / 100 \mathrm{~km}$ higher than the standard diesel car.

The electric car significantly reduces $\mathrm{CO}_{2}$ emissions because the energy efficiency of the electric car is higher than the diesel car.

The unit result can now be used to estimate total additional yearly costs assuming that 2,100 diesel taxis are replaced by electric taxis. For these taxis the additional annual cost amounts to app. EUR 6.8 million per year.

A sensitivity analysis has been carried out to establish how much larger the investment cost can be for an electric car - all other things being equal - for the social cost-benefit calculation to break even considering the reduced energy costs. The analysis shows that the price of the electric car must be reduced from DKK 400,000 to DKK 350,000. This means that the investment cost must be less than $60 \%$ larger for the social costbenefit calculation to break even.

\subsubsection{Discussion of case studies}

The cost-benefit calculations for two of the cases resulted in higher social cost for the eco-innovative product compared to the conventional product. However, as it has already been stressed, the CBA result does include all relevant effects and therefore needs to be supplemented with a discus- 
sion/assessment of the non-quantified effects and wider economic effects not included in the partial cost-benefit analysis.

The cases have many similarities. They all include higher investments costs for the eco-innovative product and they are all associated with energy savings which result in reduced energy costs and reduced external costs. Further, when non-quantified effects and wider economic effects were not considered, the conventional products resulted in the lowest social costs (except for the data centre case). As a consequence, to avoid repetitions, the discussions below are carried out only for Case number 2 - construction of buildings.

\section{Social CBA - not financial}

It should be noted that CBA calculations have a social cost perspective. The calculations have been carried out without considering or assessing the effects for the affected parties (consumer, state, society in general) separately. In practice, this means that all costs and benefits have been calculated without taxes as they just represent a transfer between the consumer and the state. However, as a consequence, the calculations do not depict the financial implications for the consumer (the public authority purchasing for example an electric vehicle).

For the cases above, the pure financial calculation for the consumer would differ from the social calculation in three ways:

- Taxes on energy would be included.

- Externalities would not be included.

- Net duty and tax distortion would not be included.

For Case 2 - construction of buildings - energy costs from a financial perspective would be 2-4 times higher due to energy and $\mathrm{CO}_{2}$ taxes. Excluding externalities, net duty and tax distortion this would mean that the calculation would result in total cost per $\mathrm{m}^{2}$ per year of approximately the same magnitude for the two alternatives. If no other effects are considered, essentially it means that energy efficient buildings might be attractive for the public authority itself but not attractive for society in general compared to the conventional building.

\subsubsection{Non-quantified effects and wider economic effects}

It is always important to supplement CBA calculations with a discussion of possible non-quantified effects.

In the case of construction of low-energy consuming buildings instead of standard buildings direct and indirect impacts normally considered in the cost-benefit analysis have been included. The impacts of air pollution have been included and there do not seem to be any other non-negligible externalities associated with the construction and operation of the buildings. 
As the case is hypothetical, it is not possible to assess whether there are differences between the two buildings other than energy consumption. Therefore, it is pragmatically assumed that the functionality, comfort level, design and other important characteristics of the two buildings are the same. If that was not the case, the impact of any difference would have to be assessed or described to supplement the quantitative CBA results.

In relation to economic assessment of policies to promote public procurement of eco-innovative products, it is especially important to consider the wider economic effects as the possible economic benefits from more innovation and "the learning curve effect" have not been considered in the CBA calculations for the three cases.

Considering the case of construction of low-energy consuming buildings instead of standard buildings it is important to note that the purchasing power of the public authorities makes up $40 \%$ of spending on construction in the EU (http://ec.europa.eu/environment/gpp/). The share is so high that it is likely that public procurement of energy efficient buildings can potentially help bringing down costs and support the development of environment-friendly products.

The figure below illustrates the potential positive effect of increasing public demand for energy efficient buildings.

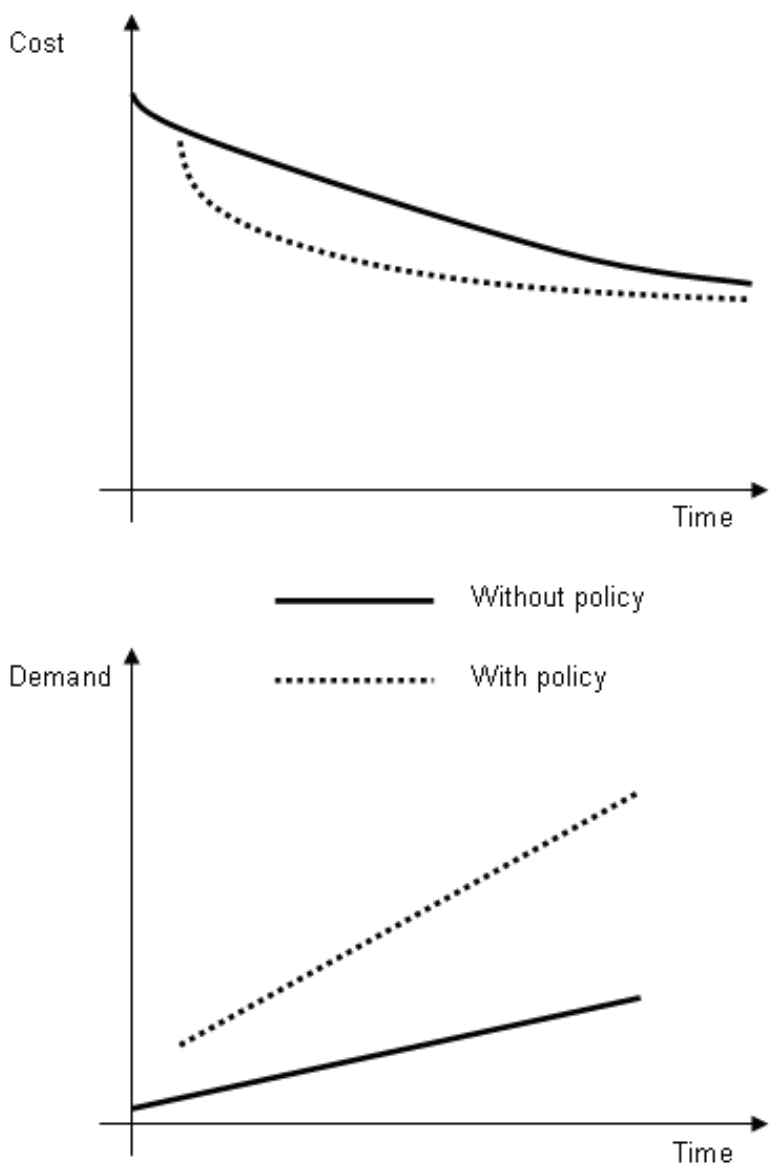

Figure 5.1Effects on learning curve and demand from increased public demand 
The figure illustrates the development of the cost of energy efficient buildings as well as the demand for energy efficient buildings with and without a policy calling for mandatory eco innovative public procurement.

For the development without regulation, the learning curve - i.e. the reduction of cost over time - is relatively limited and constant over time. Further, the demand is limited and has a low growth rate. With a policy calling for mandatory eco innovative public procurement the demand increases immediately. This affects the learning curve by reducing cost faster which in turn increases the demand for energy efficient buildings from private companies thus resulting in a higher total demand. This development leads to two social welfare gains:

- Reduced prices (from reduced costs) for the existing demand (and the demand from public procurement)

- Welfare gain in terms of increased demand compared to the nonpolicy scenario

From the case calculation it followed that the total extra cost per $\mathrm{m}^{2}$ of the energy efficient building compared to the standard building amounted to EUR 1.0. This involves higher investment costs for the energy efficient building compared to the standard building of $4.2 \%$.

From a simple break-even view with no additional demand, the extra investment cost should be reduced to app. 3.5\% for the social cost-benefit calculation to break even. This estimate is without considering the social gains from possible increased demand when costs are reduced due to the increased public demand and without considering possible positive effects stimulating technological development of products and innovation in the long run.

\subsubsection{Conclusion and perspective}

The case studies have shown that a CBA constitutes a good starting point for analysing the economic implications of eco-innovative products. However, they also showed that there are methodological and practical challenges and limitations involved in using the cost-benefit analysis to assess eco-innovative products. The level of information and knowledge is not complete which leads to uncertainties and a lack of quantification and valuation of effects.

The benefits of eco-innovative products might not be harvested without allocation of resources to support procurement processes to push forward demand. If economies of scale have not yet been achieved, costs are higher than they need to be. Support can then stimulate the market, bring down prices and in turn generate economic growth and potentially gains in social welfare. These economic and environmental benefits could po- 
tentially be achieved if schemes to promote public procurement of specific eco-innovative are implemented.

Sometimes it might be financially preferable to choose the ecoinnovative product over the standard product (e.g. the data centre case). If the standard product is selected anyhow, this can only be explained by lack of information and/or one-sided focus on low investment due to budgetary or liquidity constraints. In this case policy and decision makers should focus on removing barriers to eco-innovative procurement whether actual or perceived - and put in place the right budgetary mechanisms. Total costs in the lifetime should be in focus rather than the investment or upfront costs. 


\section{Strategical viewpoints on Innovative Green Public Procurement in Nordic Countries}

As accounted for in Section 1, the concept of "innovative procurement" differs widely from the concept of "green procurement" . While green procurement can be performed through simple selection of greener products as identified through different systems (eco-labelling, national inventories etc.), innovative procurement requires a more committed effort and entails a more significant element of risk.

Innovative Green Public Procurement IGPP entails interesting perspectives for combining the large expenditure on public procurement with the need for environmental improvements, constant innovation, and development of the Nordic business sector. But IGPP also constitutes considerable challenges due to the build-in risk element and the different barriers and obstacles previously accounted for.

The many examples from regional, national and supra-national contexts described in this report elucidate the considerable benefits that can be achieved through eco-innovative procurement. The examples and the national reviews also provide input to a set of recommendations aiming at increased and effective use of IGPP as a means of supporting environment-friendly and energy-saving technologies in the Nordic countries.

Not surprisingly, the benefits of eco-innovative procurement cannot be harvested without allocation of resources to initiate, facilitate, nurture, feed and evaluate the procurement processes. Evidently, considerable socio-economic and environmental benefits can be achieved if such resources are made available for key institutions.

\subsection{Organisational set-up}

A series of organisational elements are crucial for an effective and futureoriented implementation of eco-innovative procurement in the public sector $^{38}$. The importance of these organisational elements cannot be overestimated. Even the best practical action plan does not lead to the desired goals if the surrounding organisation is not in place.

${ }^{38}$ This section builds on literature, the previous NMRIPP Technology Procurement project, and results of the present project. 


\subsubsection{Leadership}

The lack of consistent leadership on IGPP is a key barrier. Many public sector procurers lack clear direction from the top of their organisations on the priority to be given to delivering sustainable development objectives through procurement. Even in Nordic governments there is often no clear owner of sustainable procurement. Incentive systems neither reward ecofriendly procurement nor do they punish failure to comply with existing policies in this area. Procurement officers will not engage themselves in IGPP without clear messages and support being expressed from a superior authority. All this also results in confusion for suppliers, as policy statements are not translated into procurement decisions.

By undertaking the role as national focal institution for IGPP a dedicated institution - be it a national procurement organisation, a state department or another national or sub-national entity - can ensure the necessary focus on the long-term goals and support proper organisation of each eco-innovative procurement process. Leadership means pointing out the direction, expressing visions and goals - and accepting the risk associated with departing the beaten track. Among the tasks of a focal institution are:

- Formulate, disseminate and promote the vision.

- Induce dialogue between institutions and stakeholders on how to target the vision.

- Promote establishment of user and purchaser groups enabling IGPP, i.e. setting up buyer groups.

- Launch IGPP projects and stimulate and support IGPP processes in other institutions.

- Ensure compilation and dissemination of good practice, including networking events.

- Address legal issues and develop guidelines or handbooks for procurement officers on how to minimise legal risks.

- Participate in international networks to ensure compilation and dissemination of good practice at international level, e.g. the International Energy Agency's working groups.

- Participate and support other institutions' participation in international eco-innovative procurement projects.

- Ensure monitoring of progress by external scrutiny bodies.

- Promote the eco innovation focus into R\&D institutions

The following tables describe actual institutions for eco-innovative public procurement in the four Nordic countries. 


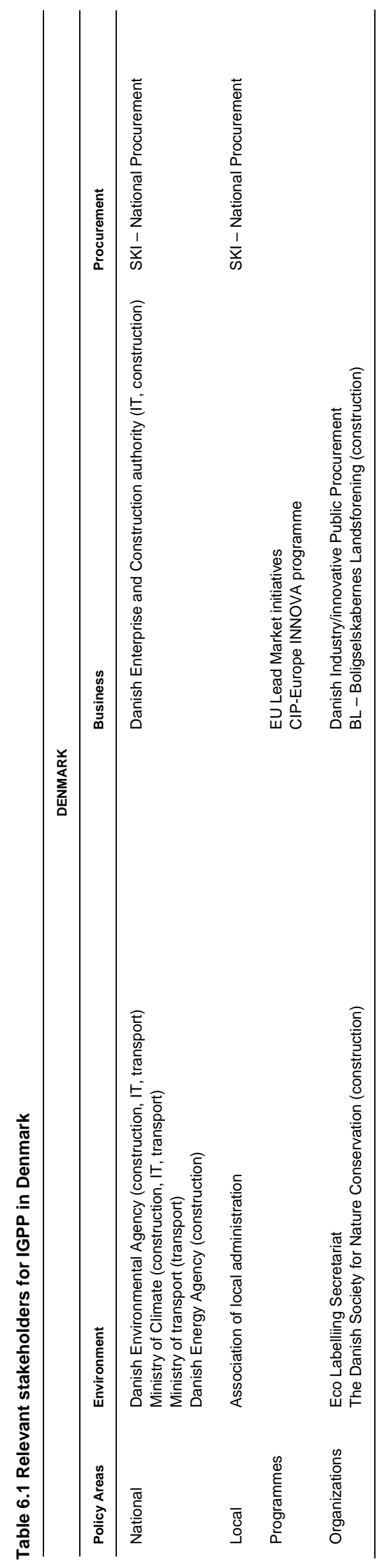




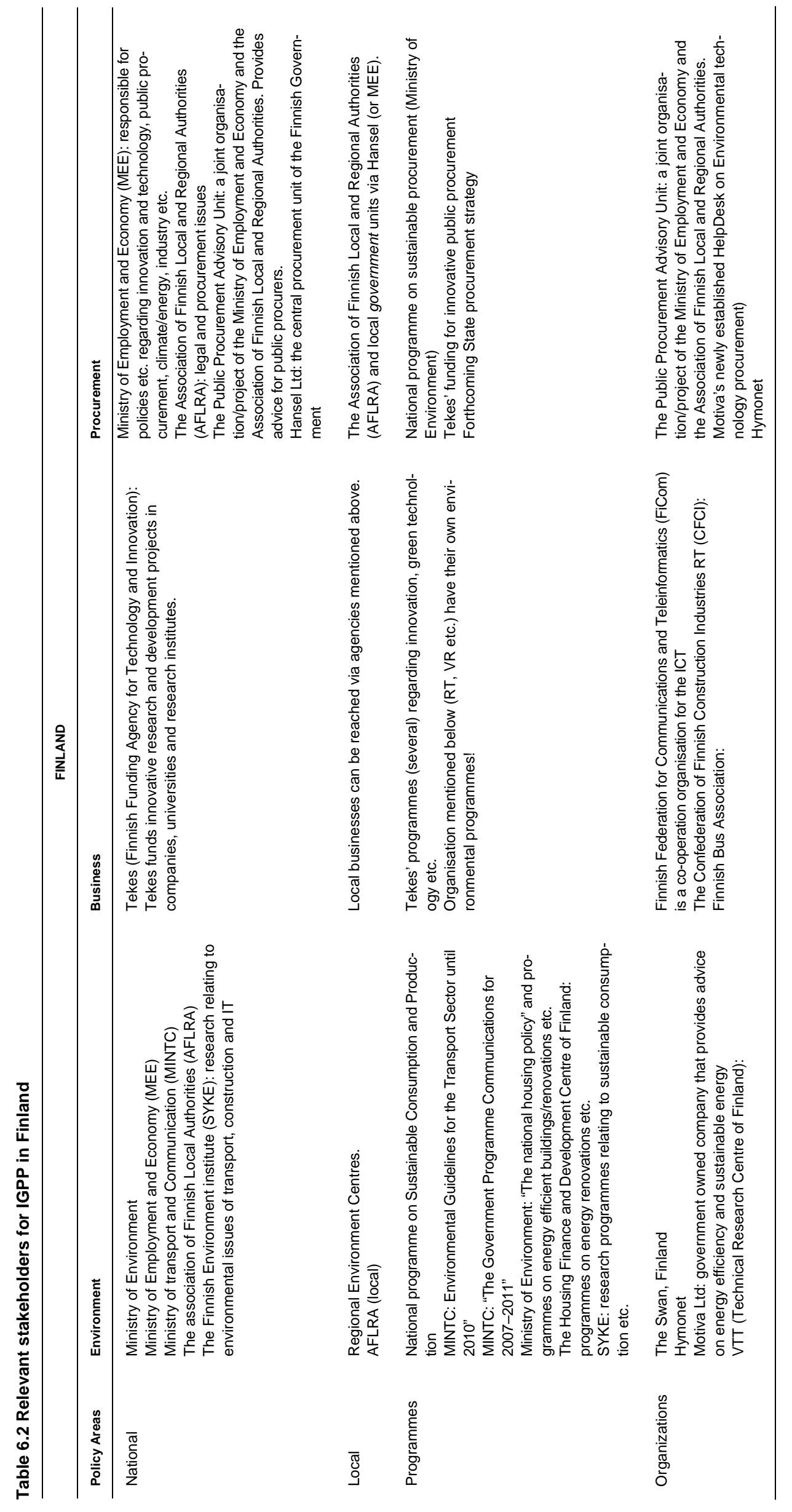




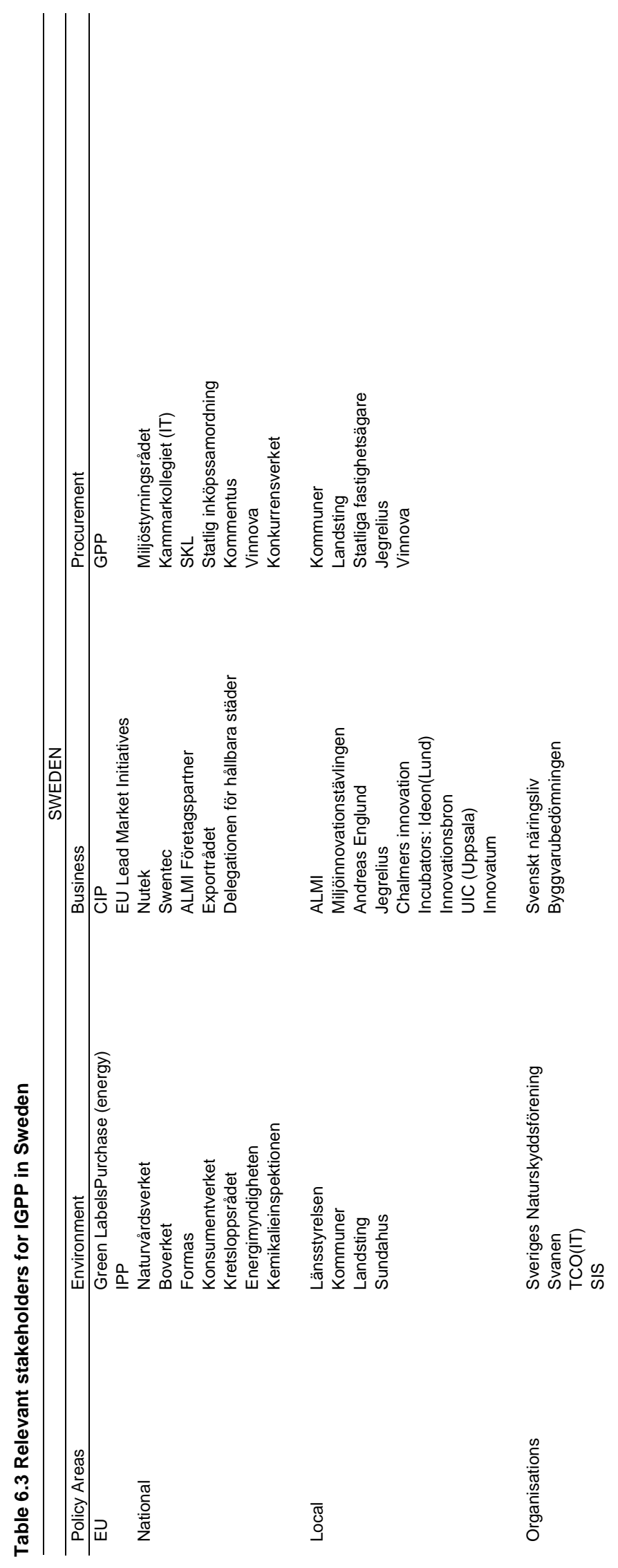




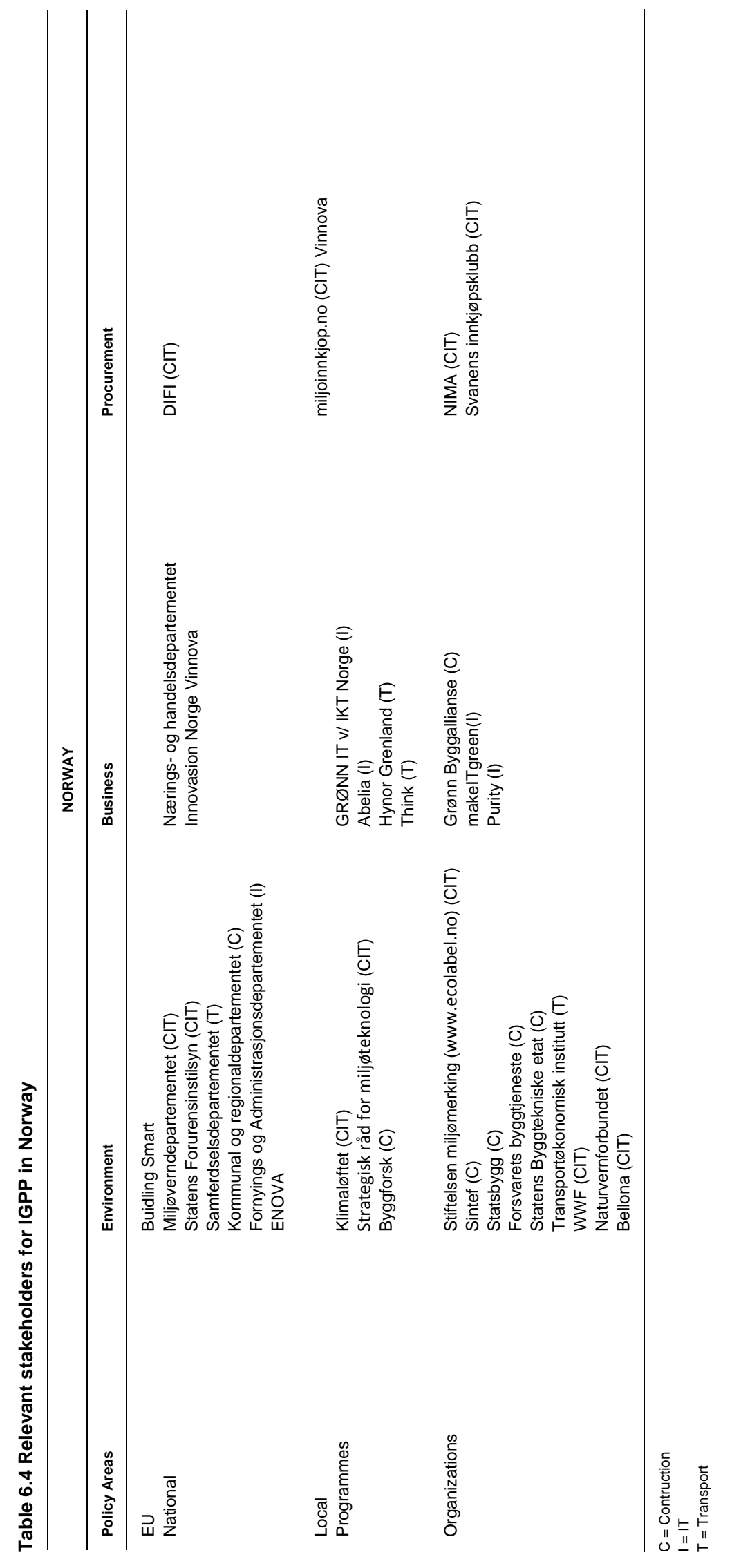




\subsubsection{Vision - political signals}

An explicit national vision expressing themes such as sustainability and greening of the public sector should draw the attention of institutions and individuals in the direction of IGPP. IGPP fits perfectly into a national development context aiming at innovation of environmentally sound technologies and a general greening of society. Such strategies and plans exist in most countries, an example is the 2007 Danish National Action Plan for Environmental Technologies (which at the moment does not deal with IGPP). As recommended by NUTEK ${ }^{39}$, it is important to see IGPP as part of an overall policy for public procurement and innovation. The Commissions initiatives with regard Lead Market Initiatives and pre-commercial procurement also support the visions for IGPP at national level.

The national vision should include clear priorities for sustainable procurement hereby rationalising the sometimes competing policies into a single integrated sustainable procurement framework.

Public procurement to support eco-innovation can initiate, escalate, or consolidate markets. In the Nordic country, the majority of green procurement policies in place are focusing on purchase of commercially available products, which escalate or consolidate the market. To improve eco-innovation more public procurement policies should focus on procurement of eco-innovations which are not yet commercialized, in other words procurement which stimulates new products to be introduced on the market. Thus, there are some initiatives already, for example the Finnish Motiva's HelpDesk on Environmental technology Procurement together with the new funding tool from TEKES of Innovative Public procurement which provide a solid basis for raising procurement competence in the area. Also the forthcoming Finnish State Procurement Strategy aims at both sustainable choices and at innovative approaches.

By streamlining innovation and environment in public procurement, procurement staff (normally focused on reducing the cost of procurement) may more proactively utilise the opportunities for playing a more dynamic role in society. The present efforts of the Finnish working group on eco-innovative procurement may lead in this direction. It should be realised that eco-innovative procurement should be based on the incentive for each public authority. If there is no incentive, no innovative procurement can be expected ${ }^{40}$.

Eco-innovative procurement is mentioned in several Swedish acts as a means to achieve environmental improvements. As in Sweden the vision could be institutionalised through inclusion in the legislative framework in the other Nordic countries.

The Norwegian Action Plan for Environmentally and Socially Responsible Procurement specifies that further measures for stimulation of

\footnotetext{
${ }^{39}$ Offentlig upphandling som drivkraft för innovation och förnyelse, Redovisning av regeringsuppdrag, R2006:21, NUTEK

${ }^{40}$ Offentlig upphandling som drivkraft för innovation og förnyelse, Vinnova 2006.
} 
eco-innovative procurement should be considered, and the Norwegian Panel for Green Public Procurement has established a working group on the theme of Public Procurement and Innovation.

\subsubsection{Strategy and Action Plans}

A road map for the inclusion of innovative environmental considerations in public procurement is necessary to most effectively pursue the vision and overall goals. With specific objectives and associated actions, the strategy elucidates the amount of resources allocated to this work field, motivates stakeholders and enables meaningful evaluation of the efforts.

Part of the strategy should focus on removing barriers to sustainable procurement - whether actual or perceived - and put in place the right budgetary mechanisms. Life Cycle Costing should be introduced, shifting the focus from lower upfront costs to attractive life cycle costs. Further, public organisations and large capital spend programmes should be reviewed to make sure they meet high sustainability standard.

The overall strategy should deal with, among others, the following areas of action:

- Prioritisation of target areas and sectors (as initiated in this project)

- Information to the market to raise the performance of both buying and selling organisations

- Investigation of effects on the procurement process

- Pilot projects

- Risk mitigation

- Sector specific efforts:

- investigation of options for cooperation between suppliers and procurers.

- $\quad$ investigation of purchaser needs

The approaches to technology procurement used in Sweden, in the US, by the International Energy Agency DSM and in the Energy+ programme are very similar, and a range of general lessons can be learned for application of the policy in the Nordic countries.

The basic methodology of an eco-innovation procurement policy programme should be structured according to the following steps:

1. Preparation of a feasibility study.

2. Establishment of a buyer group.

3. Formulation of product requirements.

4. Tendering/discussion process with innovators.

5. Evaluation of innovations.

6. Announcement (and later application) of policy support measures, including spreading of information. 
The use of Living Labs and other ways of participatory planning is gaining ground in the Nordic, and e.g. in Finland, RAKLI, the Finnish Association for Building owners and construction clients has for the past two years practiced so called procurement clinics, with roundtables and workshops with clients and possible contractors. In Sweden is established the Building- Living Dialogue project. It is a unique form of co-operation between companies, municipalities, national and local authorities, and the Government. The common goal is a sustainable building and property sector before 2025, primarily whitin three prioritised areas: the indoor environment, the use of energy and the use of natural resources.

\subsubsection{Structure}

The structure should provide a framework for public purchasers enabling them to be innovative in the purchasing process. The eco-innovative procurement examples demonstrate that the following positions should be filled:

- An active and competent purchaser group

- Facilitator and project manager - eco-innovative procurement projects are long lasting (2-4 years or even up to 8-10 years) and involve many partners, so skilled project management and facilitation is needed.

- Experts responsible for feasibility studies and other background investigations

- Purchaser group members

- Contact person to suppliers

\subsubsection{Staff}

One of the most important factors for successful innovative procurement strategies is motivated and competent staff. Motivation among procurement officers can be achieved by applying a participatory approach when conducting eco-innovative procurement projects. A clear and communicated vision for the use of eco-innovative procurement is also an important motivation factor.

As in the UK, it should be considered to develop a framework to allow public sector organisations to benchmark their own capability for ecoinnovative or sustainable procurement ${ }^{41}$.

With the exception of Sweden it seems that public purchasers and staff in relevant Nordic organisations have little or no knowledge about eco-innovative procurement. A training programme for public purchasers and other relevant personnel is a prerequisite for expanding the use of eco-innovative procurement in the Nordic countries.

One of the tasks of the focal institution is risk handling. Addressing legal and economic risks is crucial in order to motivate the procurement

\footnotetext{
${ }^{41}$ Procuring the Future, Sustainable Procurement National Action Plan, DEFRA, UK, 2006.
} 
officers to use eco-innovative procurement. The risk of using an unknown or unfamiliar methodology is a barrier that must be overcome through strong leadership and support, but also through training and pilot projects.

Thus, relevant themes for capacity building include each of the steps of eco-innovative procurement as described above, but also risk handling and economic and legal issues associated with the methodology.

\subsubsection{Systems}

Implementation of expedient systems will ease the process of ecoinnovative procurement and ensure a certain harmonisation of the national or even supra-national approach. The eco-innovative procurement methodology itself constitutes the overall system; specific development of each element of the procurement process will increase effectiveness of eco-innovative procurement and reduce the risks and uncertainties connected with the process. Finland (Motiva) is currently developing an information service on the internet, based on the elements in a procurement process in order to lift the importance of a holistic system approach within the buyer organization and to promote innovative approaches in each part of the process. There will be developed a web pages.

This process will also provide a method for public sector procurers to encourage dialogue with suppliers in key markets and will be one of the routes to the market for small and medium sized enterprises. Additional relevant systems include guidelines, case-stories, good practises and tools.

The ambition level for follow up, statistics and effectiveness assessments should be increased. Decisions should be taken on what procurement standards are mandatory and a sanction scheme for public authorities non-compliance with IGPP should be prepared.

\subsubsection{Culture}

Establishment of a culture promoting IGPP requires a long lasting effort during which leadership and communication are of vital importance. One sign of such culture is when communication of specific needs and demands from purchasers to potential developers and producers has become institutionalised and normal practice. In Iceland the tradition of close cooperation has been formalised and developed into the concept of technology forums. In Denmark the tradition of cooperation is weaker, even though experience exists within the Electricity Savings Trust. The lack of tradition - or the reduced possibilities of public-private cooperation - is an obstacle for increased use of eco-innovative procurement that must be actively dealt with.

Another cultural issue is the question of procurement officers' loyalty to processes and framework agreements in decentralised cultures such as they are found as in the Nordic countries. Genuine implementation of an 
eco-innovative procurement strategy requires continuous focus on the ability and will among organisations and individuals to act as desired.

\subsection{Proposed key contents in possible action plans on IGPP in Nordic countries}

Successful seeking of eco-innovative solutions necessitates clear processes for the identification of needs and timely and effective engagement with the market ${ }^{42}$. Below are highlighted a number of important activities necessary for enabling more eco-innovation in relation to the selected product groups (construction, IT and transport services) through proactive public procurement.

The action plans should naturally be founded and further developed on tha basis of the existing bilateral national and sectoral plans and policies in the Nordic countries.

\subsubsection{Organisation of tenders in two steps}

A central precondition for enabling eco-innovative processes is extended communication with the complete value chain combined with thorough assessment of needs and technical/organizational opportunities.

New models for tendering are needed especially for procurement of construction work and IT. "Two step tendering" has provided valuable results in terms of integrating new technological and organisational solutions with environmental requirements:

1. Interaction and dialogue between the organisation inviting tenders and the potential tenderers concerning needs, options/solutions and possible ways forward.

2. The actual tendering process.

This procedure for organisation of tenders is also prescribed in the "competitive dialogue procedure" introduced in the public sector procurement directive (2004/18/EC) and implemented in the Public Contracts Regulation (SI 2006/5) which came into force 31. January 2006. It is for use in the award of complex ocntracts, where there is a need for the contracting authorities to discuss all aspects of the proposed contract with candidates.

National level institutions should identify appropriate models for more dialogue in tender processes. Especially regarding tenders for construction work (a complex sector with solutions adapted to local conditions), dialogue is needed if the desired services and products should go beyond standardised solutions.

42 Finding and Procuring Innovative Solutions; Department for Innovation, Universities and Skills, the UK Office of Government Commerce, 2007. a 
Within the transport sector it is relevant to provide incentives that stimulate use of vehicles with alternative fuels or with fuel-saving technology. Thus, initiatives to provide and secure the necessary infrastructure for alternative fuels should be activated at the same time.

\subsubsection{Performance based tender criteria}

In public tenders it is common to use criteria based on specific technical standards concerning e.g. limit values for $\mathrm{SO} 2$ emissions or particles. However, using technically based criteria requires considerable technical knowledge in the public procurement institutions and need for regular updating of this knowledge. To enable more eco-innovative solutions, performance based criteria are a useful alternative instrument to ensure an open scope for solutions. Performance based criteria are easy to use in tender processes and they provide an "innovative room" for the supplier. An example of performance based criteria could be "lowest possible CO2 emission pr. km transport”. Thus, this is not a requirement as such but an award criteria. This means the tender can offer high CO2 emission and still be awarded the contract. To be sure to award a contract with low $\mathrm{CO} 2$ emission, the performance criteria should be supplemented with a stated maximum emission level.

Especially in relation to procurement of IT services, performance criteria should be applied more widely, e.g. for energy use and data capacity. By using performance criteria for IT services, chances for getting the newest technologies are higher. In the survey, several examples of tender processes ending up with old technologies were identified. The typical situation is, that the procurement process takes approx. three years from issuing the tender to receiving the equipment and meanwhile the technological development have overtaken the specifications in the tender and "state of art" IT equipment is far ahead in performance, than the delivered (which fully complete the specifications written three years ago). By using performance criteria it is possible to ensure "state of art" equipment at delivery date. This can be further enhanced by using contract constructions which include incentives for continuous improvements, or value engineering. To ensure that equipment or services is in accordance with the technical development, contract clauses should be applied

National initiatives for ensuring incorporation of performance criteria for energy use etc. in tenders for procurement of IT services should be established.

\subsubsection{Framework agreement with risk sharing}

For IT services and construction, it is relevant to consider a wider use of framework agreements with selected eco innovative suppliers where the procurement institution is willing to test and buy products without the 
traditional standard documentation and guarantees. Some division of risk between procurement institution and suppliers is necessary if new products and services are to be developed. The construction sector is highly influenced by standards and requirements on documentation and this culture is a barrier for enhanced development of eco-innovative solutions. The need for more examples of eco-innovative construction work may be met through increased use of framework contracts.

A responsible national coordination body should initiate policy development and dialogue with relevant procurement institutions and supplier representatives concerning point of views and models on risk sharing in connection with public procurement of construction work.

6.2.4 Extended use of dedicated EU programmes for public procurement of innovation supporting measures.

EU has initiated specific programmes to promote innovation and ecoinnovation. Of particular relevance is the Lead Market initiative focusing on developing new markets through a.o. dialogue and public demands.

The Competitiveness and Innovation Framework Programme (CIP) aims to support innovation activities (including eco-innovation), provide better access to finance and deliver business support services in the regions. It will encourage a better take-up and use of information and communications technologies (ICT) and help to develop the information society. It will also promote the increased use of renewable energies and energy efficiency.

LIFE + is a limited but focused funding instrument providing specific support for the development and implementation of Community environmental policy and legislation and resulting thematic strategies. It will co-finance projects that contribute to the implementation of a.o. the development of innovative policy approaches, technologies, methods and instruments.

The Seventh RTD Framework Programme (2007-2013) dedicates considerable support to the development of environmental technologies. In addition to traditional collaborative research, FP7 provides support to technology platforms and Joint Technological Initiatives which are large initiatives implemented in public/private partnerships. Environmental technologies research is included across different themes of the Framework Programme, in particular in environment, energy and transport.

The Nordic participation in these programmes has been relatively sparse and utilization of these funding opportunities might be improved. The CIP programme is in particular dedicated to eco-innovation initiatives within IT services, Life+ is dedicated to policy level, capacity building and awareness raising, Seventh framework programme is especially focusing on transport and energy saving, and Lead Market covers a.o. construction work. 
Both at national level and Nordic level, initiatives for specific ecoinnovative projects should be developed to ensure external funding for further progress with eco-innovative public procurement. Thus, Motiva and Culminatum Innovation from Finland are participating in a EUfunded LMI-project concerning sustainable construction network for public procurers and Kolding municipality from Denmark participates in the EU funded “Smart SPP” project.

\subsubsection{Development of eco-innovative procurement policy programmes}

At national level the competent body should develop an IGPP policy programme for selected product groups - structured according to the method described in section 6.1.3.

\subsubsection{Improved integration of Life Cycle Cost in public procurement}

In general, there is a need for more knowledge and information about the particular life cycle cost when evaluating proposals. Especially for construction work and for IT services, the life cycle cost is an important part of the decision making. Legal initiatives should be considered to ensure more documentation on LCC from suppliers during the tender process as a part of decision making.

Further, coordination between the procurement body and the operational body, e.g. in relation to housing, should in general be improved and the main criteria for selection of products/services should be based on cheapest in a life cycle perspective (up front + operating cost) and not, as common today, the up front cost only.

\subsubsection{Financial support where stimulation is necessary}

The socio economic survey of the scenarios within the selected product groups provides a number of interesting points. Strict economic logic dictates that the market for eco-innovative IT server systems will increase automatically due to the technologies” obvious economic benefits. But so far experience shows that this is still far from the case. National efforts should therefore be made in terms of information campaigns and more demonstration projects, serving as inspiration for public procurers of IT systems. Also catalytic procurement and activities may serve as drivers for users, within or beyond the public sector.

For low energy buildings the situation is different. Economic estimates indicate that low energy buildings are not economically feasible even in a long term perspective with the stated cost for standard and low energy buildings. With present energy prices and under the given assumptions, the procuring organisation must accept a certain price rise compared to traditional construction techniques. 
Regulatory actions are taken from the EU, e.g., in the form of a Directive on energy labelling of buildings and requirements for low energy standards in all new building constructions etc. However, it may very well be considered of particular interest for the Nordic countries to be first movers within this sector, since the Nordic countries have many material suppliers, consultants and contractors as well as an attractive platform for export of product and services. National efforts should therefore focus on activating instruments, such as tax reductions, direct financial support, regulation etc. to boost development of eco-innovative buildings.

In relation to taxi services national attention should be on providing the necessary infrastructure and incentives for introduction and use of alternative vehicles, e.g. based on electricity.

\subsubsection{Spreading and multiplying best practises}

When the Nordic experiences with IGGP will exceed in the coming years, it is important to ensure appropriate coordination and dissemination of best practise. Not only at national level but also at the Nordic level. Initiatives to coordinate this dissemination among the Nordic countries, should be established.

\subsection{Ideas concerning action plans for construction work}

To understand the particular context of this sector strengths and weaknesses are summarized:

Strengths

- Numerous eco-innovative solutions have been invented and pilot tested

- Huge international experience exists with implementation of ecoinnovative solutions

- Strong competition among construction companies

- Huge international interest for eco-innovative construction

- Good tradition for process dialogue between building owner and construction companies

- Contractors and sub-suppliers are known for reacting quickly on specific needs - decisions are taken locally

- Especially the many small construction companies can respond immediately to needs and wishes

- Many international programmes and funds support eco-innovative construction (including EU programmes such as ETAP, Lead Market etc.)

\section{Weaknesses}

- The public building owners' funds for construction and operation are divided between different budgets 
- Lack of pro-active interest for eco-innovation among construction companies and architects

- Historically not much cooperation in the product chain, collaboration is temporary and project based

- The sector's profit margin is typically low

- The project culture of the sector hinders systematic compilation and dissemination of good eco-practices

- The countless actors in the sector impede broad dissemination of good practice

- Infrastructural requirements may constitute a specific weakness

On the basis of the above considerations above, the following table summarizes elements to be included in a targeted action plan for developing eco-innovation in construction work in the Nordic countries.

Table 6.5 Proposals for actions to stimulate eco innovation within construction work

\begin{tabular}{|c|c|c|}
\hline Task & Problem & Actions \\
\hline Leadership & $\begin{array}{l}\text { Lack of political leadership request- } \\
\text { ing sustainable building solution at } \\
\text { municipal and county level }\end{array}$ & $\begin{array}{l}\text { - Formulation of strategy and policy for } \\
\text { PP of construction work } \\
\text { - More information of environmental and } \\
\text { economic benefits } \\
\text { - Capacity building of public authority } \\
\text { decision makers }\end{array}$ \\
\hline $\begin{array}{l}\text { Organizing the } \\
\text { procurement }\end{array}$ & $\begin{array}{l}\text { Lack of coordination between pro- } \\
\text { curers and between procurers and } \\
\text { users of building facility }\end{array}$ & $\begin{array}{l}\text { - Procedure in tender process ensuring } \\
\text { coordination of users and use of experi- } \\
\text { ence from operation of similar buildings } \\
\text { - Assessment of budget calculations } \\
\text { which include Life Cycle Cost }\end{array}$ \\
\hline $\begin{array}{l}\text { Environmental } \\
\text { dialogue with } \\
\text { suppliers }\end{array}$ & $\begin{array}{l}\text { There is a need for improving ongo- } \\
\text { ing dialogue between client and } \\
\text { contractors during the planning and } \\
\text { construction phases }\end{array}$ & $\begin{array}{l}\text { - requirement in tender that an envi- } \\
\text { ronmental work group will be estab- } \\
\text { lished } \\
\text { - establishing an environmental work } \\
\text { group to ensure integration of sustain- } \\
\text { able solutions throughout the planning } \\
\text { and construction phase }\end{array}$ \\
\hline Legal framework & $\begin{array}{l}\text { The legislative framework, especially } \\
\text { at level of local spatial planning, sets } \\
\text { limits for eco-innovation }\end{array}$ & $\begin{array}{l}\text { - Attention, know-how and willingness } \\
\text { among authorities to issue dispensa- } \\
\text { tions to building projects which propose } \\
\text { alternative solutions in relation to } \\
\text { sewage treatment, energy supply, } \\
\text { waste handling, water supply. }\end{array}$ \\
\hline Resources & $\begin{array}{l}\text { There is a lack of venture capital to } \\
\text { develop eco-innovative building }\end{array}$ & $\begin{array}{l}\text { - leadership, assessment of life cycle } \\
\text { cost and risk acceptance }\end{array}$ \\
\hline $\begin{array}{l}\text { Technology } \\
\text { procurement }\end{array}$ & $\begin{array}{l}\text { Experience shows that advanced } \\
\text { demands can be provided by con- } \\
\text { tractor by using technology pro- } \\
\text { curement }\end{array}$ & $\begin{array}{l}\text { - change tenders where relevant in } \\
\text { direction of technology procurement }\end{array}$ \\
\hline Capacity building & $\begin{array}{l}\text { There is a need for improved capac- } \\
\text { ity in public procurement of environ- } \\
\text { mentally sustainable buildings }\end{array}$ & $\begin{array}{l}\text { - checklists and similar tools for public } \\
\text { procurers } \\
\text { - coordination between operational staff, } \\
\text { users and procurement } \\
\text { - training in building technologies and } \\
\text { technology procurement methods }\end{array}$ \\
\hline
\end{tabular}




\subsection{Ideas concerning action plans for IT products and services}

To understand the particular context for this sector, the following strengths and weaknesses are summerized.

Strengths

- Good eco-innovative potential for server systems

- High innovative focus in IT sector

- Innovation is driven by technology push which are ahead of the general market demands

- Environment is a well known issue for hardware suppliers

- Nordic market is a trend spot market

Weaknesses

- Small Nordic market

- Lack of updated technical competences in public sector

- Difficult to define standard applicable solutions

- Long procurement processes

- Lack of environmental focus in utilizing software

- No influence on basic development of core technologies

- Lack of local political leadership

- Difficult to update knowledge combining procurement of hardware and software

On the basis of the above considerations above, the following table summarizes elements to be included in a targeted action plan for developing eco-innovation for IT product and services in the Nordic countries. 
Table 6.6 Proposals for actions to stimulate eco innovation within ITk

\begin{tabular}{|c|c|c|}
\hline Task & Problem & Actions \\
\hline Leadership & $\begin{array}{l}\text { There is a lack of political leadership } \\
\text { requesting eco-innovative IT solu- } \\
\text { tions at municipal and county level }\end{array}$ & $\begin{array}{l}\text { - Formulation of environmental IT } \\
\text { strategy and policy } \\
\text { - More information about environmental } \\
\text { and economic benefits } \\
\text { - Capacity building of public authority } \\
\text { decision makers }\end{array}$ \\
\hline $\begin{array}{l}\text { Organizing the } \\
\text { procurement }\end{array}$ & $\begin{array}{l}\text { There is a lack of coordination } \\
\text { between procurers and between } \\
\text { procurers and users of IT }\end{array}$ & $\begin{array}{l}\text { - Integrate Code of Conduct on data } \\
\text { centre energy efficiency when procuring } \\
\text { server systems } \\
\text { - Procedure in tender process ensuring } \\
\text { coordination to users } \\
\text { - Assessment of budget calculations } \\
\text { which include Life Cycle Cost }\end{array}$ \\
\hline $\begin{array}{l}\text { Environmental } \\
\text { dialogue with } \\
\text { suppliers }\end{array}$ & $\begin{array}{l}\text { There is a need for ensuring envi- } \\
\text { ronmental consideration in procure- } \\
\text { ment of server systems and concepts } \\
\text { in corporation with suppliers }\end{array}$ & $\begin{array}{l}\text { - environmental specifications to hard- } \\
\text { ware and software suppliers } \\
\text { - ensure solutions integrated with overall } \\
\text { design }\end{array}$ \\
\hline $\begin{array}{l}\text { Technology } \\
\text { procurement }\end{array}$ & $\begin{array}{l}\text { Experience show that advanced } \\
\text { demands can be provided by } \\
\text { contractor by using technology } \\
\text { procurement }\end{array}$ & $\begin{array}{l}\text { - change tenders where relevant in } \\
\text { direction of technology procurement }\end{array}$ \\
\hline Capacity building & $\begin{array}{l}\text { There is a need for improved capac- } \\
\text { ity in public procurement of eco- } \\
\text { innovative IT solutions }\end{array}$ & $\begin{array}{l}\text { - checklists and similar tools to public } \\
\text { procure } \\
\text { - coordination between users and } \\
\text { procurement } \\
\text { - training in procurement based on } \\
\text { function description }\end{array}$ \\
\hline
\end{tabular}

\subsection{Ideas concerning action plans for taxi and bus services}

To understand the particular context for this sector, the following strengths and weaknesses are summerized.

\section{Strengths}

- Good eco-innovative potentials for improving the various communication systems

- High innovative focus on energy efficiency and emission reduction

- Environment is a well known issue for car manufacturers

Weaknesses

- Difficult to influence basic innovations through public procurement demands.

- Long procurement processes

- Need for investment in transport infrastructure

- No influence on basic development of core technologies

- Poor economy in public transport tenders 
On the basis of the above considerations above, the following table summarizes elements to be included in a targeted action plan for developing eco-innovation for taxi and bus services in the Nordic countries.

Table 6.7 Proposals for actions to stimulate eco innovation within construction work

\begin{tabular}{|c|c|c|}
\hline Task & Problem & Actions \\
\hline Leadership & $\begin{array}{l}\text { There is a lack of political leader- } \\
\text { ship }\end{array}$ & $\begin{array}{l}\text { - Formulation of environmental strategy } \\
\text { and policy }\end{array}$ \\
\hline $\begin{array}{l}\text { Organizing the } \\
\text { procurement }\end{array}$ & $\begin{array}{l}\text { There is a lack of coordination } \\
\text { between procurers and between } \\
\text { procurement and users. }\end{array}$ & $\begin{array}{l}\text { - make databases on best practise } \\
\text { technologies available for procurement } \\
\text { - encourage consultants to assist in the } \\
\text { tender process to improve eco- } \\
\text { innovative solutions }\end{array}$ \\
\hline $\begin{array}{l}\text { Environmental } \\
\text { dialogue with } \\
\text { suppliers }\end{array}$ & & $\begin{array}{l}\text { - environmental specifications distrib- } \\
\text { uted to operators before tender }\end{array}$ \\
\hline $\begin{array}{l}\text { Technology } \\
\text { procurement/pre } \\
\text { commercial } \\
\text { procurement }\end{array}$ & $\begin{array}{l}\text { Experience shows that advanced } \\
\text { demands can be provided by } \\
\text { contractors by using technology } \\
\text { procurement principles }\end{array}$ & $\begin{array}{l}\text { - change tenders where relevant in } \\
\text { direction of technology procurement }\end{array}$ \\
\hline Capacity building & $\begin{array}{l}\text { There is a need for improved } \\
\text { capacity in public procurement of } \\
\text { eco-innovative solutions }\end{array}$ & $\begin{array}{l}\text { - checklists and similar tools for public } \\
\text { procurers } \\
\text { - coordination between users and } \\
\text { procurement } \\
\text { - training in procurement based on } \\
\text { function description }\end{array}$ \\
\hline Infrastructure & $\begin{array}{l}\text { There is a need for establishing the } \\
\text { necessary infrastructure for utilizing } \\
\text { eco-innovative technologies, e.g. } \\
\text { based on alternative fuel or ITS } \\
\text { concepts. }\end{array}$ & $\begin{array}{l}\text { - coordinate efforts with infrastructural } \\
\text { planning }\end{array}$ \\
\hline
\end{tabular}

The innovative potential is probably most interesting with regard to ITS. But implementation of ITS systems is generally part of a larger traffic planning strategy and is not related to GPP. Hence, the area will not be discussed further here.

The use of environmental requirements in the procurement of existing technologies/solutions helps promote eco-innovations and should be used more, and more ambitiously in PP. GPP, LCC etc. are still new to some procurers. Procurement guidelines for PP should include all significant environmental aspects of procurement. 



\section{Sammenfatning}

I projektet anvendes betegnelsen Innovative Offentlige Grønne Indkøb ((Innovative Green Public Procurement - IGGP). IGGP er offentlige indkøb, der stimulere miljø-innovation gennem efterspørgsel og samspil med leverandører og andre interessenter med det formål at forbedre den miljømæssige profil i produkter og serviceydelser.

IGGP karakteriseres ved følgende punkter:

1. Produkterne har været gennem en innovativ proces, som har medført en ny organisatorisk eller teknologisk standard

2. Produkterne er indkøbt af offentlige institutioner

3. Den innovative proces har medført miljømæssige forbedringer

4. Leverandøren/leverandørerne er fra den private sektor

I projektet er der foretaget en vurdering af volumen i det offentlige indkøb i de forskellige nordiske lande samt en vurdering af miljøforhold for de største produktgrupper indenfor offentlige indkøb. På den baggrund er der blevet prioriteret tre produktgrupper, der er særligt interessante i et nordisk perspektiv. De tre produktgrupper er:

- Bygge og anlægsarbejde

- IT server systemer

- Offentlige transport ydelser

Det miljø-innovative potentiale for de tre udvalgte grupper er blevet analyseret med henblik på at skabe et overblik over, hvilke potentialer der eksisterer for IGGP indenfor de valgte produktgrupper i de forskellige nordiske lande.

Analysen omfatter:

- Definering af det miljø-innovative potentiale for hver af de tre produktgrupper

- Vurdering af den miljømæssige effekt ved IGGP

- Relevante incitamenter for stimulering af miljø-innovation gennem offentlige indkøb

- Barrierer for at udnytte det miljø-innovative potentiale

- Input til strategier for innovative grønne offentlige indkøb 


\section{Anbefalinger til Nordisk handlingsplan for IGGP}

For at miljø-innovative løsninger skal lykkes, er det en forudsætning, at der gennemføres konkrete aktiviteter der afdækker behovet samt at der sikres et effektivt samarbejde mellem markedet og offentlige indkøbere. Handlingsplanen bør naturligvis tage udgangspunkt i allerede eksisterende sektorplaner og politikker i de respektive nordiske lande.

\section{Todelt organisering af udbud}

Det er en central forudsætning for miljø-innovative processer, at kommunikationen med den samlede værdikæde intensiveres samtidig med at der gennemføres en grundig vurdering af behov og teknologiske/organisatoriske muligheder.

Der er behov for nye modeller for udbud, ikke mindst ved offentlige udbud af byggeri og IT-ydelser. Når udbud gennemføres i to faser, opnår man et samspil mellem teknologiske og organisatoriske løsninger samt de miljømæssige krav. De to faser består af:

1. Samspil og dialog mellem den udbydende organisation og de potentielle tilbudsgivere angående behov, muligheder og løsninger samt mulige fremtidige skridt.

2. Den faktiske udbudsproces.

Denne procedure for organisering af tilbud er ligeledes foreskrevet i proceduren for "konkurrencepræget dialog” som nævnt i EU's direktiv for offentlige indkøb (2004/18/EC) og gennemført i Forordning om offentlige aftaler (SI 2006/5), som trådte i kraft 31. januar 2006. Proceduren anvendes ved tildeling af mere komplekse kontrakter, hvor udbyderen har behov for at diskutere alle aspekter vedrørende den aktuelle kontrakt med de potentielle tilbudsgivere.

Statslige organisationer bør i løbet af udbudsprocessen afklare, hvilke modeller for yderligere dialog, der er hensigtsmæssige. Det kan være nødvendigt med yderligere dialog, hvis man ønsker et resultat ud over standardløsninger. Dette gælder ikke mindst i byggebranchen, hvor løsninger ofte er tilpasset lokale forhold.

I transportsektoren er det relevant at anvende incitamenter, der kan stimulere brugen af transportmidler med alternativt brændstof eller med brændstofbesparende teknologi. Samtidig bør det sikres, at den nødvendige infrastruktur for sådanne transportmidler tilvejebringes.

\section{Udbudskriterier baseret på funktionskrav}

Det ses ofte, at offentlige udbud anvender kriterier baseret på tekniske standarder vedrørende fx grænseværdier for SO2-udledninger eller partikler. Det kræver dog omfattende teknisk viden hos den offentlige udbyder såvel som løbende opdatering at anvende disse tekniske kriterier. For at 
bane vejen for mere miljø-innovative løsninger er kriterier baseret på funktionskrav et oplagt alternativ. Kriterier baseret på funktionskrav er enkle at anvende i udbudsprocessen og de giver "innovativ plads" til leverandøren. Et eksempel på et sådant kriterium baseret på funktionskrav kunne være "lavest mulige $\mathrm{CO}_{2}$-udledning pr. km transport". Dermed er det ikke et egentlig krav, men et tildelingskriterium. Dette betyder, at leverandøren kan tilbyde høje $\mathrm{CO}_{2}$-udledninger og stadig vinde kontrakten. For at sikre, at kontrakten baseres på lave $\mathrm{CO}_{2}$-udledninger, skal funktionskravet suppleres med et klart angivet maksimalt udledningsniveau.

Særligt hvad angår indkøb af IT-ydelser bør funktionskrav anvendes i større omfang, fx hvad angår energiforbrug og datakapacitet. Ved at anvende funktionskrav for IT-ydelser øger man muligheden for at anskaffe seneste teknologi. Der blev i undersøgelsen afdækket flere eksempler på udbud, hvor der blev indkøbt gammel teknologi. Typisk tager udbudsprocessen ca. tre år at regne fra udbudsinvitationen til udstyret er endeligt leveret, og i dette tidsrum vil den teknologiske udvikling have overhalet udbudsspecifikationerne og "state of art" IT udstyr vil være kommet langt videre end det leverede udstyr (som lever fuldt ud op til de specifikationer, der blev formuleret tre år tilbage). Ved at anvende kriterier baseret på funktionskrav kan man sikre "state of art" udstyr, når man kommer frem til levering. Dette kan yderligere forstærkes ved at anvende kontrakttyper, som indeholder incitamenter for løbende forbedringer eller såkaldt value engineering (omkostningsoptimering). Specifikke klausuler i kontrakterne kan være en hensigtsmæssig måde at sikre sig, at udstyr og tjenesteydelser følger den teknologiske udvikling.

Der bør indføres nationale initiativer til at sikre indarbejdning af funktionskrav for energiforbrug etc. i udbud vedrørende IT tjenesteydelser.

\section{Rammeaftale med risikodeling}

Når man laver udbud for IT tjenesteydelser og byggeri, kan man med fordel overveje at gøre mere brug af rammeaftaler med udvalgte miljøinnovative leverandører i de tilfælde, hvor indkøberen er parat til at teste og anskaffe produkter uden gængs standarddokumentation og garantier. Det vil kræve en vis deling af risikoen mellem indkøber og leverandør, såfremt man ønsker at få udviklet nye produkter og tjenesteydelser. Byggebranchen er i høj grad præget af standarder og krav til dokumentation, og denne kultur er en barriere for vidtgående udvikling af miljøinnovative løsninger. Behovet for flere eksempler på miljø-innovativt byggeri kan opfyldes ved at anvende rammekontrakter i højere grad.

Initiativet til politikudvikling og dialog med relevante indkøbsorganisationer og repræsentanter for leverandør angående holdninger til og modeller for risikodeling i forbindelse med offentlige udbud af byggeri bør komme fra et centralt, ansvarligt koordinerende organ. 
Udvidet brug af dedikerede EU programmer for offentlige indkøb med innovative incitamenter.

EU har igangsat særlige programmer for at fremme innovation og miljøinnovation. Deltagelse fra de nordiske lande i disse programmer har været ret lav og disse finansieringsmuligheder kunne anvendes i højere grad. Rammeprogrammet for konkurrenceevne og innovation (CIP) henvender sig særligt til miljø-innovative initiativer indenfor IT, mens Life+ henvender sig til den politiske sfære, kapacitetsopbygning og forøgelse af miljøbevidsthed. Det syvende rammeprogram fokuserer specielt på transport og energibesparelser, mens Lead Market initiativet (LMI) bl.a. dækker byggeri.

Både på statsligt niveau og på nordisk niveau bør der udvikles initiativer for specifikke miljø-innovative projekter for at sikre ekstern finansiering med henblik på at gøre yderligere fremskridt indenfor miljøinnovative offentlige indkøb. For eksempel deltager Motiva og Culminatum Innovation fra Finland i et EU-støttet LMI-projekt vedrørende et bæredygtigt byggerirelateret netværk for offentlige indkøbere og Kolding Kommune fra Danmark deltager i det EU-støttede “Smart SPP” projekt.

\section{Udvikling af programmer for miljø-innovativ indkøbspolitik}

På det nationale niveau bør en kompetent myndighed udvikle et IGGP politisk program for udvalgte produktgrupper.

\section{Øget integrering af livscyklusomkostninger i offentlige indkøb}

Generelt er der behov for store viden og information om de specifikke livscyklusomkostninger, når man evaluerer indkomne tilbud. Specielt hvad angår byggeri og IT-tjenesteydelser er livscyklusomkostninger et vigtigt element i beslutningsprocessen. Det bør overvejes at indføre lovgivning for at sikre bedre dokumentation af livscyklusomkostninger fra leverandører i udbudsprocessen som en del af beslutningsprocessen.

Yderligere bør koordineringen mellem udbyderorganisationen og brugerorganisation forbedres, $\mathrm{fx}$ indenfor boliger, og hovedkriteriet for valg af produkter/ydelser bør være baseret på det laveste tilbud i en livscyklusbetragtning (investering samt driftsomkostninger) og ikke som det normalt sker i dag kun den umiddelbare investering.

\section{Finansiel støtte hvor stimulering er nødvendig}

For lavenergibyggeri er billedet anderledes. Cost benefit vurderinger foretaget i projektet tilsiger, at lavenergibyggeri ikke er økonomisk gennemførligt, selv på langt sigt, når man ser på omkostninger for standardversus lavenergibyggeri. Med dagens energipriser og givne forudsætninger må indkøbsorganisationen acceptere en øget pris sammenlignet med traditionelle byggeteknikker. 
Der findes EU lovgivning på området, fx i form af et direktiv om energimærkning af bygninger og krav til lavenergistandarder $\mathrm{i}$ alle nye byggerier etc. Det kunne dog være af særlig interesse for de nordiske lande at tage teten i denne sektor, da de nordiske lande har mange leverandører af byggematerialer, rådgivere og entreprenører samt et attraktivt udgangspunkt for eksport af produkter og serviceydelser. Nationale tiltag bør derfor fokusere på initiativer, der kan sætte gang i udviklingen af miljø-innovativt byggeri, såsom skattebegunstigelse, direkte økonomisk støtte, lovgivning etc.

Inden for taxiydelser bør man nationalt fokusere på at stille den nødvendige infrastruktur til rådighed samt skabe incitamenter for indførelse og brug af alternative køretøjer, fx eldrevne biler.

Formidling og udspredelse af best practise

Efterhånden som der høstes erfaringer med IGGP i de nordiske lande i de kommende år, er det vigtigt at sikre vidtgående koordinering og formidling af best practise - ikke kun nationalt men på nordisk plan. Der bør igangsættes initiativer, der kan koordinere denne formidling blandt de nordiske lande. 



\section{References}

\section{List of contacts}

Jan Peter Amundal, Enova

Ulf Blomqvist, Atea

Isa Maria Bergmann, Motiva Finland Jens Petter Burud, energy expert, YIT Søren Bo Christiansen, IT-specialist, SKI Peter Defranceschi: ICLEI: Simon Clement, Mark Hidson

Rikke Dreyer, Statens og kommunernes indkøbsservice (SKI), Denmark

Henrik Egede, IT-Branchen

Andreas Englund, Environmental Innovation Market (MInT)

Tore Evensen, Alcatel Lucent Norway

Gert S. Hansen, Miljøstyrelsen

Michael Flor Hansen, Teknologisk

Johnny Hansen, Arriva

Benedikt Halfdanarson, Statistics Iceland Catarina Hedar, Swentec, Swedish Environmental Technology Council.

Ric Hettinga, programdirectorate Sustainable Procurement, Ministry of Environment and Spatial Planning, The Netherlands

Katarina Johansson, Statistics Sweden

Monique Lempers, PriceWaterhouse Coopers

Mette Lise Jensen, Miljøstyrelsen

Denmark

Peter Rørmose Jensen, Statistics Denmark

Dagmar Kase, Federal Environmental

Agency, Germany

Krogsgaard Milena A, EPNN

Jill Michielssen et. al, EU commission

Expert-network for GPP, (all members

of the networks have been contacted)

Jonas Møller, Dansk Byggeri

Anne Mette Nielsen PriceWaterhouse Coopers, Denmark

Tania Nikula, Ministry of Environment, Finland

Peter Nohrstedt, The Swedish Environmental Management Council

Anders Nyquist, Anarcab, Sweden

Keld Jersild Olsen, Manageing director HP, Denmark

Pianoo, Ilse A.D. Fatehmahomed, The Netherlands.
Sven-Erik Rehnman, Fujitsu Siemens, Denmark

Remy Risser, Ministère de l'écologie, du développement et de l'aménagement durable, France.

Hege Skodje, project coordinator, Alternativ Data, Norway

Michael Svane, Direktør DI Transport, Denmark

Aime Võsu, Adviser, Public Governance Department, Ministry of Finance of Estonia

Kristian Widén Division of Construction Management, Lund University

Other references

/1/ Commission of the European Communities; Brussels 04.08.18; Buying Green! A handbook on environmental public procurement

/2/ Naturvårdsverket; rapport 5445; jan 2005; Miljöanpassad offentlig upphandling En enkätstudie 2004

/3/ Department for Environment, Food and Rural Affairs; 2006; Procuring the Future. Sustainable Procurement National Action Plan: Recommendations from the Sustainable Procurement Task Force

/4/ Miljøstyrelsen; 2001; arbejdsrapport nr. 15; Grøn elektronik i offentlige indkøb

/5/ Center for alternativ samfundsanalyse; 2001; Notat, mens vi venter på de grønne indkøbere

/6/ Danmarks Naturfredningsforening; 2007; Grønne indkøb - en enestående motor for miljørigtige produkter

/7/ Økonomi- og erhvervsministeriet; Veje til en grøn erhvervsudvikling

/8/ Environmental Impact of Products (EIPRO), Analysis of the life cycle environmental impacts related to the final consumption of the EU-25, Main Report, IPTS/ESTO project, Arnold Tukker et al., may 2006

/9/ Eurostat - input-output tables

/10/ Statistics Denmark, www.dst.dk

/11/ Statistics Norway, http://www.ssb.no

/12/ Statistics Sweden, http://www.scb.se/

/13/ Statistics Finland, http://www.stat.fi 
/14/ EU priority groups: http://ec.europa.eu/ environment/gpp/toolkit_en.htm

/15/ Current survey regarding EU GPP: www.thevalueofgreen.com

/16/ Finansministeriet, 1999: Vejledning i udarbejdelse af samfundsøkonomiske konsekvensvurderinger, 1999

/17/ Energistyrelsen, 2007: Teknologivurdering af alternative drivmidler til transportsektoren, COWI for Energistyrelsen, 2007

/18/ Energistyrelsen, 2008: Forudsætninger for samfundsøkonomiske analyser på energiområdet, februar 2008

/19/ Miljøstyrelsen, 2007: Metoder til samfundsmæssig vurdering af miljøeffektiv teknologi, COWI for Miljøstyrelsen, 2007

/20/ OECD, 2006: Cost-Benefit Analysis and the Environment - Recent Developments, 2006

/21/ Transportøkonomiske enhedspriser vers 1.0, feb08.xls

/22/ Børsen Klima, Article 15. july 2009 concerning biogas busses.

/22/ Göthenberg et al, ITPS, IT och miljö Aktuella initiativ i Japan och USA, R2008:006

/23/ Andreas Englund, Framgångsrika miljöinnovationer- en studie av 113 svenska innovationer från tävlingen miljöinnovation, nov 2007

/24/ Swentecs rapport till regeringen 2008 Vägen mot en effektiv struktur för svensk miljöteknik

/25/ Naturvårdsverket, rapport5806, Lokala miljöinvesteringar ger globala avtryck. /26/ LIP, Local Investment Programmes, was a large programme for ecological sustainability under the last Swedish Government

/27/ Energismart och kretsloppsanpassat byggande i kallt klimat, www.ac.lst.se/ miljomal

/28/ Computers and the environment, 2003, Kuehr \& Williams

/29/ Swentecs rapport till regeringen 2008 Vägen mot en effektiv struktur för svensk miljöteknik

/30/ Innovation Systems and Environmental Technologies - Cross-sectoral analysis and policy implications”. TemaNord 2008:565. Released by Norden in 2008

/31/ The danish ministry of environmental concerns: Development with thoughtfulness - common responsibility; chapter 6 :
Miljøstyrelsen; Udvikling med omtanke

- fælles ansvar, 2001

/32/ Newsletter nr. 218 from the technology council, www.tekno.dk/pdf/ nummer218.pdf

/33/ Environmental adjustments in municipal purchases: Miljöanpassad kommunal upphandling i Örebro län: www.orebro.se

134/ A memo from the government july 2006: Regeringens skrivelse; 2006/07:54;Miljöanpassad offentlig upphandling: http://www.iclei-europe.org/ fileadmin/template/projects/procuraplus/ New_website/Reference_Documents/ NPA_Sweden.pdf

/35/ Revised note concerning greenbook about an integrated product policy: Revideret grundnotat. Vedrørende grønbog om en integreret produktpolitik KOM (2001) 68 final version

/36/ Competitive Dialogue Procedure: OGC Guidance, January 2006. Office of Government Commerce

/37/ Precommercial procurement: Driving innovation to ensure sustainable highquality public services in Europe". COM (2007), 799

/38/ How central authorities can support ecodesign. Company perspectives, Nordisk Ministerråd,, 2008.

www.norden.org/da/publikationer/publik ationer/2008-569/

/39/ Energy efficiency in the Nordic building sector. Nordisk Ministerråd, 2009.

www.norden.org/sv/publikationer/publikat ioner/2009-562?set_language $=$ sv

\section{Websites}

Common measures: Gemensamma åtgärder: http://www.w.lst.se/upload/ 5615/Gemensamma.pdf

Desciption of a project about green public procurement from the council of Västernorrland: Projektbeskrivning för miljöanpassad upphandling: http://www.y. komforb.se/Filer/mauverb.pdf

www.acento.no/xp/pub/venstre_hovedmeny/ acento_environment/life_cycles/index.html http://app.bastaonline.se/SearchProducts.aspx Procurment service for the public sector in Germany: http://www.bescha.bund.de/ cln_048/DE/Home/homepage_node.ht $\mathrm{ml}$ ?_nnn=true

www.byggvarubedomningen.se/sa/node.as p?node $=305$

www.byggabodialogen.se 
www.ecma-international.org/publications/ standards/Ecma-370.htm

www.elsparefonden.dk www.digi.no/php/art.php?id=520254 www.gesi.org/index.php?article_id=47 www.gesi.org/files/2007_gesi_report.pdf page 7

www.gronnit.no/files/File/Verktoykasse/Ti ps\%20til\%20Gr\%C3\%B8nn\%20IT\%20 Endelig.pdf

www.idg.no/computerworld/tema/gronnit/ article107572.ece www.kretsloppsradet.se

www.metric.no

Procurement service for the public sector in England: http://online.ogcbuyingsolutions. gov.uk/index.html?slis_checked=1

PIANOo in The Netherlands is a web-page for Public procures: http://www.pianoo.nl/ www.steria.no/gloria/id/11004337/subid/0 www.symbiocity.org/ 